\begin{tabular}{lllllllllll}
\hline M & I & S & C & E & L & L & A & N & E & A
\end{tabular}

OLGA MIRIAM PRZYBYŁOWICZ

Instytut Archeologii i Etnologii PAN

\title{
RACHUNKI PREPOZYTA KLASZTORU ŚW. DUCHA DE SAXIA W KRAKOWIE MACIEJA REGIOMONTANUSA Z LAT 1570-1591. ŚWIAT LUDZI I RZECZY
}

Przedmiotem analizy jest najstarsza zachowana księga rachunkowa krakowskiego klasztoru św. Ducha de Saxia. Rękopis, pochodzący z drugiej połowy XVI w., spisany został przez prepozyta wspólnoty Macieja Regiomontanusa, pochodzącego z Królewca, w latach

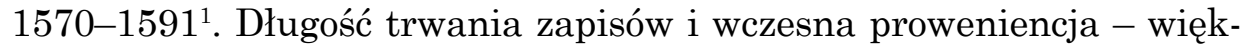
szość zachowanych rachunków duchaków dotyczy nie klasztoru (kolejne rozliczenia konwentu zachowały się z 1650 r. ${ }^{2}$ ), a szpitala - sprawia, że jest to rękopis cenny. Tym bardziej że jest on jedna $\mathrm{z}$ najstarszych ksiag wydatków polskich klasztorów, gdyż większość zachowanych do naszych czasów pochodzi z XVII, a przede wszystkim XVIII i XIX w. ${ }^{3}$

${ }^{1}$ Biblioteka Jagiellońska, Oddział rękopisów nr 6387, mkf Biblioteka Narodowa nr 43085. Dziękuję BN za jego udostępnienie do dłuższych badań (dalej: BJ 6387 Rachunki).

${ }^{2}$ Biblioteka Naukowa PAU i PAN w Krakowie, sygn. 1063, Regestr prowentów konwentu krakowskiego zakonu św. Ducha przez X Albina Komorowicza faktora od czasów kapituły prowincjonalnej pisać poczęty (1650 r.) (materiał ten będzie przedmiotem mojego osobnego studium).

${ }^{3}$ Najstarsze rachunki zachowały się z początku XVI w., pochodzą z konwentów: krakowskich augustianów: Dochody i wydatki Konwentu Braci Eremitów św. Augustyna przy kościele św. Katarzyny w Kazimierzu. Ze zbiorów Archiwum Państwowego $w$ Krakowie, wyd. K. Jelonek-Litewka i in., t. 1: 1502-1505, t. 2: 1506-1508, Kraków 2002-2004; oraz krakowskich dominikanów: M. Zdanek, Dochody dominikanów krakowskich $w$ 1. połowie XVI w., w: Inter oeconomiam coelestem et terrenam. Mendykanci a zagadnienia ekonomiczne, red. W. Długokęcki i in., Kraków 2011 (Studia i Źródła Dominikańskiego Instytutu Historycznego w Krakowie, 9), s. 259-271; a także cysterek w Trzebnicy, Das Trebnitzer Rechnungbuch von 1523-1524, wyd. H. Grüger, Marburg 1986. Ponadto z drugiej połowy XV w. pochodza zapisy gospodarcze kanoników regularnych: Biblioteka PAU i PAN w Krakowie, Katalog rękopisów Biblioteki Polskiej Akademii Nauk $w$ Krakowie, sygnatury 1811-2148, oprac. Z. Jabłoński, 
Z tych powodów rękopis jest wielce interesujacym źródłem do poznania sposobu funkcjonowania wspólnoty zakonnej o specyficznym charakterze - nastawionej na pomoc potrzebującym w dużym mieście, jej finansów, ekonomii, w końcu więzi społecznych w skali mikro - w obrębie placówki i makro - w relacjach konwentu ze światem zewnętrznym.

Charyzmatem zakon św. Ducha, założonego we Francji w drugiej połowie XII w. przez Gwidona z Montpellier ${ }^{4}$, była opieka, tak fizyczna, jak i duszpasterska nad biednymi, chorymi i sierotami w szpitalach-przytułkach ${ }^{5}$. Do Polski sprowadził zakonników w 1220 r. biskup krakowski Iwo Odrowąż, osadzając ich na Prądniku pod Krakowem. Duchak Wojciech Bazeusz ze Szczebrzeszyna ${ }^{6}$ w spisanej w XVI w. historii zakonu przywoływał rok 1204 i akcję biskupa Pełki, który miał umieścić zakonników i szpital w Sławkowie. Z tego powodu starsza literatura przedmiotu przyjmowała za datę fundacji klasztoru i szpitala 1204 r. ${ }^{7}$ Klara Antosiewicz wykazała jednak, że daty tej nie da się utrzymać ${ }^{8}$. Dyskusja w literaturze przedmiotu dotyczyła także klasztoru macierzystego krakowskiego zgromadzenia. Wynikała ona z niejasnego zapisu źródłowego „de Vienna”. Starsi badacze wskazywali na francuskie Vienne, w którym kanonicy św. Augustyna byli od XII w.,

A. Preisner, Wrocław-Warszawa-Kraków 1962, nr 1967, Księga rachunków gospodarczych klasztoru kanoników regularnych w Kłobucku z lat 1466-1518; Z. Perzanowski, Spominki klasztoru kłobuckiego, „Rocznik Muzeum Okręgowego w Częstochowie" 1,1985 , s. 95-118.

${ }^{4}$ Nazwa de Saxia pochodzi od rzymskiej placówki ufundowanej przez papieża Innocentego III w 1204 r., znajdującej się w dzielnicy o tej nazwie.

${ }^{5}$ M. Surdacki, L'Ospedale di Santo Spirito di Roma come esempio dell'apostolato della misericordia, „Dolentium Hominum. Chiesa e Salute nel Mondo” 47, 2001, nr 2, s. 64-72; tenże, Dzieci porzucone w Szpitalu Świętego Ducha w Rzymie w XVIII wieku, Lublin 1998; tenże, Szkoła dla chłopców przy Szpitalu Świętego Ducha w Rzymie w XVI-XVIII wieku, „Roczniki Nauk Społecznych” 27, 1999, nr 2, s. 105-121; Źródta normatywne kościelne jako podstawa do badań nad szpitalnictwem $w$ Polsce przedrozbiorowej, „Roczniki Nauk Społecznych” 18, 1990, nr 2, s. 57-70.

${ }^{6}$ Archiwum Generalne Sióstr Kanoniczek Ducha Św. de Saxia w Krakowie, Epitome Xenodochii M. Alberti Basaeli Scebresinensis fr. Ordinis S. Spiritus, Cracovia 1570, k. 16.

${ }^{7}$ L. Wachholz, Szpitale krakowskie 1220-1290, t. 1, Kraków 1921, s. 7; S. Tomkowicz, Szpital św. Ducha, w: Zabytki budownictwa m. Krakowa, cz. 1, Kraków 1892, s. 12 .

${ }^{8}$ Po pierwsze z powodu śmierci biskupa w 1207 r., po drugie ze względu na wczesną faze rozwoju osadnictwa w Krakowie i jego okolicy. Jaką rację bytu i cel miałaby fundacja placówki o tym charakterze w tak wczesnym okresie, gdy Kraków nie był jeszcze miastem w sensie prawno-przestrzennym, a Sławków niewielką osadą o nieznanej wielkości i liczbie mieszkańców. Komu mieliby pomagać duchacy?; K. Antosiewicz, Zakon św. Ducha de Saxia w Polsce, „Nasza Przeszłość” 23, 1966, s. 173, 174. 
Antosiewicz zaś opowiedziała się za Wiedniem, gdzie klasztor duchaków został fundowany w $1211 \mathrm{r} .{ }^{9}$ Jej ustaleń nie zakwestionowali kolejni badacze.

Poza sporem pozostaje data przeniesienia zakonników do Krakowa, na obrzeża przedlokacyjnego miasta. Uczynił to, jak podaje Jan Długosz, biskup Prędota 6 IV 1244 r. ${ }^{10}$, który przeniósł zgromadzenie z Prądnika, oddając mu parafialny kościół św. Krzyża. Wystawił ponadto klasztor oraz szpital połaczony z budynkiem innej świątyni św. Ducha, a także kościół parafialny w Biskupicach koło Wieliczki ${ }^{11}$. Uposażenie pierwotne duchaków stanowiły wsie: Krowodrza, Prądnik, Wronin Duży oraz Mały, Błędowo (zamienione na dziesięciny przez biskupa Prędotę), ponadto ogrody na przedmieściu Wieliczki i Kleparza. W drugiej połowie XIV w. otrzymali oni jeszcze pastwiska nad Prądnikiem od Spytka z Dzietrzychowic, w 1418 r. królowa Elżbieta Granowska, żona Jagiełły, dodała Wolę i Rzankę, a Kurdwanów w 1525 r. podarowała przełożona duchaczek ${ }^{12}$. Klasztor od połowy $\mathrm{XV}$ w. miał według Długosza w wymienionych wsiach jedno sołectwo, cztery karczmy, dziewięć sadzawek i 28 ogrodów oraz nieokreśloną ilość łąk i folwarków, ponadto dziesięciny z 13 wsi i dochody z prebendy kościoła św. Benedykta na Krzemionkach ${ }^{13}$. Podstawą utrzymania placówki szpitalnej były natomiast czynsze i legaty zapisywane od XIV w. przez szlachtę, a przede wszystkim mieszczan krakowskich ${ }^{14}$.

\footnotetext{
${ }^{9}$ Tamże.

${ }^{10}$ Długosz w Rocznikach wspominał o bp. Iwo jako fundatorze szpitala, a w Liber beneficiorum o Prędocie; Joannis Dlugosii, Annales seu cronicae incliti Regni Poloniae, ks. 1-12, Varsaviae-Cracoviae 1964-2003; przekład polski: Jana Dtugosza Roczniki, czyli Kroniki Stawnego Królestwa Polskiego, ks. 1-12, Warszawa 1961-2004, tu ks. 5-6, s. 294-295; Joannis Dlugosii senioris canonici Cracoviensis, Liber beneficiorum dioecesis Cracoviensis, t. 1-3, w: Opera omnia, t. 8-10, wyd. A. Przezdziecki, Kraków 1863-1864, tu t. 3, s. 38-49.

${ }^{11}$ Biskup zachował jednak w Biskupicach prawo prezenty kandydata, co było zgodne z tendencją sprawowania kontroli przez hierarchów w XIII w. w procesie przechodzenia kościołów w ręce zakonne; M. Zdanek, Klasztor jako instrument reformy Kościoła. Przykład diecezji krakowskie (połowa XII - połowa XIII w.), w: Klasztor $w$ kościele średniowiecznym i nowożytnym, red. M. Derwich, A. Pobóg-Lenartowicz, Warszawa-Wrocław-Opole 2010, s. 377-392, tu s. 388. De facto kapłani-zakonnicy pojawili się tam pod koniec XV w., a wcześniej byli to duchowni świeccy; A. Chojnacki, Inkorporacje kościołów parafialnych do klasztorów w przekazie Liber Beneficiorum Jana Dtugosza, w: Klasztor w gospodarce średniowiecznej i nowożytnej, red. M. Derwich, Wrocław 2013, s. 361-378, tu s. 376.

${ }^{12} \mathrm{~S}$. Tomkowicz, dz. cyt., s. 70 n. (edycja dokumentu bp. P. Tomickiego).

${ }^{13}$ J. Długosz, Liber beneficiorum..., t. 3, s. 40 n.

${ }^{14} \mathrm{~K}$. Antosiewicz, Opieka nad dziećmi $w$ zakonie świętego Ducha $w$ Krakowie (1220-1788), w: Z badań nad dziejami zakonów i stosunków wyznaniowych na ziemiach
} 
Na temat duchaków, więcej jednak o szpitalu i jego działalności niż klasztorze, pisali jedynie Stanisław Tomkowicz ${ }^{15}$ oraz Klara Antosiewicz, i to przede wszystkim o jego średniowiecznych dziejach ${ }^{16}$. Pewien wpływ na taką sytuację ma stan zachowania źródeł - średniowieczne akta i biblioteka zostały zniszczone podczas wielkiego pożaru Krakowa w 1528 r., a nowożytne uległy rozproszeniu po kasacie zgromadzenia przez prymasa Michała Poniatowskiego i śmierci ostatniego duchaka krakowskiego w 1788 r. ${ }^{17}$ Zachowało się więc jedynie dziewięć książek rękopiśmiennych, 57 inkunabułów, ponad 50 rękopisów (w tym większość rachunkowych, o czym poniżej) w różnych instytucjach naukowych oraz 336 starodruków z XVI-XVIII w. ${ }^{18}$ i akta luźne ${ }^{19}$.

Rachunki klasztorne stanowia od lat jeden $\mathrm{z}$ niedostatecznie wykorzystywanych typów źródeł do poznania życia wspólnotowego, choć zainteresowanie nimi wzrosło $\mathrm{w}$ ostatnich latach ${ }^{20}$. Badacze uświada-

polskich, red. E. Wiśniowski, Lublin 1984, s. 45-88. Zachował się regestr czynszów, legatów z 1595 r., który wymienia 56 kamienic, 3 jatki i 3 kramy, z których prowizorzy pobierali czynsze; Archiwum Narodowe w Krakowie (dalej: ANKrak.), rkps nr 3399.

${ }^{15} \mathrm{~S}$. Tomkowicz, dz. cyt.

${ }^{16}$ K. Antosiewicz. Zakon św. Ducha de Saxia..., s. 167-188; taż, Zachowane źródta do dziejów zakonu Ducha Św. de Saxia w Polsce, „Archiwa, Biblioteki, Muzea Kościelne w Polsce” 20, 1970, s. 95-143; taż, Zakon kanoników regularnych Ducha Świętego de Saxia w Krakowie, w: Studia z dziejów Kościoła św. Krzyża w Krakowie, t. 1, red. Z. Kliś, Kraków 1996, s. 11-28; taż, Opieka nad dziećmi...; taż, Biblioteki zakonu Ducha Św. w Polsce, „Archiwa, Biblioteki, Muzea Kościelne w Polsce” 41, 1980, s. $354-370$.

${ }^{17}$ W. Chotkowski, Ks. Prymasa Poniatowskiego spustoszenie kościelne w Krakowie, Kraków 1918. Trzech duchaków w 1783 r. przeniósł Poniatowski do klasztoru księży emerytów przy ul. Grodzkiej, naprzeciw kościoła św. Marcina, tamże powędrowały ich zbiory, a następnie po wejściu Prusaków do miasta i przeniesieniu księży emerytów do klasztoru kanoników regularnych od pokuty przy kościeleśw. Marka. Inkunabuły i druki z XVI-XVIII w. zabrała krakowska kapituła katedralna pod koniec XVIII w., a na początku XIX w. reszta zbiorów uległa rozproszeniu, a część przeniesiona została do skarbca przy kościele św. Marka. W 1954 r. niewielki procent tychże zbiorów trafił do Biblioteki Seminarium Duchownego w Krakowie i do Archiwum Kurii Metropolitalnej; K. Antosiewicz, Zachowane źródta..., s. 97; taż, Biblioteki..., s. 356.

${ }^{18}$ K. Antosiewicz, Zachowane źródta..., s. 97; taż, Biblioteki..., s. 356.

${ }^{19}$ ANKrak., rkps 3319, Kopiariusz zapisów na rzecz klasztoru kanoników regularnych de Saxia 1512-1712; ANKrak., rkps 3320, Registrum confraternitas Sancti Spritus 1566-1647; ANKrak., rkps 3321, Akta dotyczące klasztoru kanoników de Saxia (akta luźne) 1539-1782; ANKrak., rkps 3455, Ordinationes te decreta visitationis hospitalis S. Spiritus Cracovie; ANKrak., rkps 3457, Visitatio externa et interna hospitalis sancti Spiritus et calculatio de perceptis proventibus et expensis 1738 expedita; ANKrak., rkps 3458, Akta do szpitala św. Ducha 1335-1799.

${ }^{20}$ Korzysta z nich systematycznie A. Szylar, Gospodarowanie benedyktynek sandomierskich, Tarnobrzeg 2008, s. 135 n.; taż, Działalność handlowa benedyktynek sando- 
miają sobie ich potencjał, jednak żmudność badań, a niekiedy trudność w dotarciu do źródeł znajdujących się w klasztornych archiwach powoduje, że niewielu po nie sięga. Znacznie większą uwagą cieszą się rachunkowe akta szpitalne. Były one przedmiotem zainteresowania Marka Słonia w odniesieniu do placówek Wrocławia ${ }^{21}$, edycję zaś źródeł gdańskich przygotował Adam Szarszewski ${ }^{22}$. Natomiast kolekcja tego typu archiwaliów z klasztoru duchaków krakowskich nie była nigdy przedmiotem badań. Jest ona imponująca. W Archiwum Narodowym w Krakowie znajduje się $55 \mathrm{ksiag}$ rachunkowych szpitala z lat 1561$-1817^{23}$, a kilka rękopisów, nie tylko rachunkowych, przechowywanych

mierskich w XVIII i XIX wieku, „Studia Historyczne” 48, 2005, s. 167-189; taż, Rzecz o tym, jak benedyktynki kuchnię prowadzity, „Nasza Przeszłość” 103, 2005, s. 189-224. Ponadto prezentowała je P. Gasiorowska, Rola ksień klarysek krakowskich $w$ zarzadzie majatkiem ziemskim do końca XVIII w., w: Inter oeconomiam coelestem..., s. 537-557; taż, Obrót gotówka w klasztorze żeńskim na przykładzie osiemnastowiecznych ksiag rachunkowych wybranych klasztorów krakowskich i lwowskich, w: Klasztor $w$ gospodarce..., s. 303-318. Rachunki analizowały także: M. Borkowska, Rachunki benedyktynek kowieńskich, „Nasza Przeszłość” 106, 2006, s. 261-278; D. Burdzy, „Percepta et expensa”. Budżety obu klasztorów dominikańskich w Sandomierzu w XVIII w., $\mathrm{w}$ : Klasztor $w$ gospodarce..., s. 319-345. O istnieniu cennych, bo pochodzących z początku XVI w. rachunków benedyktynów tynieckich wspomina, choć wykorzystuje marginalnie: T.M. Gronowski, Zwyczajny klasztor, zwyczajni mnisi. Wspólnota tyniecka $w$ średniowieczu, Kraków 2007. O rachunkach konwentów żeńskich w diecezji krakowskiej zob. O.M. Przybyłowicz, Jak panny zakonne rozliczały się? Księgi rachunkowe jako źródto do badań nad polskimi klasztorami żeńskimi w XVI-XVIII w., w: Klasztor w gospodarce..., s. 101-115; taż, Rachunki klasztorne jako źródto do poznania realiów życia klasztornego. Najstarsza zachowana księga rachunkowa klarysek ze Starego Sacza, w: Realia życia codziennego w Europie Środkowej ze szczególnym uwzględnieniem Ślaska, red. A. Barciak, Katowice 2011 (Kultura Europy Środkowej, 14), s. $197-220$.

${ }^{21}$ M. Słoń, Ludzie z rachunków klasztornych. Przykład szpitala św. Ducha we Wrocławiu, w: Klasztor $w$ społeczeństwie średniowiecznym i nowożytnym, red. M. Derwich, A. Pobóg-Lenartowicz, Opole-Wrocław 1996, s. 445-452; tenże, Średniowieczne rachunki szpitali wrocławskich, „Kwartalnik Historyczny” 105, 1998, nr 2, s. 17-32; tenże, Blisko źródta czy czytelnika? Refleksje na marginesie edycji rachunków szpitalnych z 1495 r., „Studia Źródłoznawcze” 45, 2007, s. 65-70; tenże, Szpitale średniowiecznego Wrocławia, Warszawa 2000; M. Słoń, U. Sowina, Die Badestube des Heilig-Geist-Spitals zu Breslau, w: Quellen zur europäischen Spitalgeschichte in Mittelalter und Früher Neuzeit / Sources for the History of Hospitals in Medieval and Early Modern Europe, red. M. Scheutz i in., Wien-Munchen 2010, s. 563-580.

${ }^{22}$ Najstarsze księgi rachunkowe szpitali gdańskich. Księga rachunkowa szpitala Bożego Ciała (l. 1580-1581), księga rachunkowa zjednoczonych szpitali św. Ducha $i$ św. Elżbiety (l. 1585-1593), oprac. i wyd. A. Szarszewski, Torun 2005 (Hospitalia Gedanensia. Fontes, 5).

${ }^{23}$ ANKrak., Akta Miasta Krakowa, sygn. 3397a, Regestr wydania i przyjęcia na szpital Świętego Ducha tego do roku 1561; ANKrak., sygn. 3398, Regestry szpitalne 
jest w Bibliotece Jagiellońskiej i Bibliotece PAN ${ }^{24}$. Z kolei nowożytne rachunki dotyczace zgromadzenia duchaczek, począwszy od najstarszych z 1763 r., zwane Księgami kasowymi i Księgami finansów, znajdują się w Archiwum Generalnym sióstr w Krakowie ${ }^{25}$. Do tej pory rękopisy rachunkowe duchaków były wykorzystane w niewielkim stopniu, a rachunki Regiomontanusa w ogóle. $\mathrm{Z}$ wybranych ksiąg expensów i perceptów szpitalnych duchaków korzystała Klara Antosiewicz, sporządzając rejestr zatrudnienia mamek oraz zestawienia nauczycieli pracujaccych w szkole. Przeglądała bowiem księgi rachunkowe z lat 1601-1612, 1642, 1650, 1671-1687, 1694 oraz osiemnastowieczne ${ }^{26}$.

Wiedza o dziejach krakowskiego zgromadzenia oraz prowadzonej przez nich placówki opiekuńczo-zdrowotnej, jak napisał Krzysztof Ożóg: „największego w Krakowie średniowiecznego szpitala, który odpowiadał na ważne potrzeby społeczności miejskiej”, oraz funkcjonującej przy konwencie szkoły dla świeckich, nadal jest jednym ze słabiej oświetlonych zagadnień w porównaniu do prac powstałych na temat innych męskich krakowskich klasztorów w średniowieczu i nowożytności ${ }^{27}$.

św. Ducha 3.1.1562-31.12 1562; ANKrak., sygn. 3399, Regestra szpitalne św. Ducha 1595-1596; ANKrak., sygn. 3400-3410, Regestra hospitalis s. Spiritus de Saxia z lat 1601-1613 (ciagłe); ANKrak., sygn. 3411-3452, Regestra hospitalis s. Spiritus de Saxia z lat 1617-1812 i 1817.

${ }^{24}$ Rachunki zob. przyp. 1 i 2 . Ponadto BJ, rkps 6385 III, Protokoły posiedzeń kapituł prowincjonalnych zakonu św. Ducha 1634-1783; BJ, rkps 7044 I, Ustawy życia mniszek zakonu św. Ducha; Biblioteka Naukowa PAN i PAU, Kopiariusz duchaków, rkps 7117; Zakład Narodowy im. Ossolińskich we Wrocławiu, rkps 633/1.

${ }^{25}$ Archiwum Generalne Kanoniczek św. Ducha de Saxia, Księgi kasowe domów zgromadzenia, sygn. KK od 1,1 (1763) do początku XX w. oraz Księgi finansów zgromadzenia sygn. KF 1 (1766-1836), KF 2 (1835-1875), KF 3 (1875-1929), KF 4 (1776-1942); ANKrak., Akta miasta Krakowa, Akta luźne duchaczek 1690-1780, rkps 3322 oraz fragment rkps EM 8.

${ }^{26}$ K. Antosiewicz, Opieka nad dziećmi..., s. 70-72, 75-88.

${ }^{27}$ K. Ożóg, Klasztorna geografia średniowiecznego Krakowa, w: Klasztor $w$ mieście średniowiecznym i nowożytnym, red. M. Derwich, A. Pobóg-Lenartowicz, Wrocław-Opole 2000, s. 217-235; H. Gapski, Klasztory krakowskie w końcu XVI i w pierwszej połowie XVII w. Analiza przestrzenna środowisk zakonnych, Lublin 1993, tam o duchakach zaledwie kilka informacji, s. 70, 80, gdyż autor nie obją ich szczegółowymi badaniami. Inne zgromadzenia cieszą się zainteresowaniem badaczy od lat, przede wszystkich systematycznie ukazują się publikacje o zakonach żebrzących, a szczególnie dominikanach (w serii Studia i Źródła Dominikańskiego Instytutu Historycznego w Krakowie, zob. przyp. 3), kanonikach od pokuty zwanych markami (Studia z dziejów kościoła św. Marka w Krakowie, red. Z. Kliśs, Kraków 2001; A. Bruździński, Kanonicy regularni od pokuty na ziemiach polskich, Kraków 2003), augustianach (W. Kolak, Klasztor augustianów przy kościele św. Katarzyny w Krakowie do połowy XVI w. Fundacja, rozwój uposażenia i rola kulturalna, Kraków 1982; T.M. Trajdos, Fundacja klasztoru benedyktynów słowiańskich na Kleparzu w Krakowie, „Rocznik Krakowski” 
Klasztory duchackie męski i żeński wraz ze szpitalem oraz szkołą uległy spaleniu podczas wielkiego pożaru Krakowa w 1528 r. Informacja o nim zachowała się m.in. w dokumencie pergaminowym, który odnaleziono w gałce wieży kościoła św. Krzyża ${ }^{28}$. Z aktu innowacyjnego wydanego przez bp. Piotra Tomickiego 18 X 1528 r. oraz wizytacji bp. Jakuba Zadzika z 1638 r. ${ }^{29}$ wynika, że wówczas klasztor zawarł z miastem umowę, na mocy której prowizorami szpitala mieli być odtąd zawsze rajcy krakowscy, w zamian za co miasto dało fundusze na odbudowę szpitala ${ }^{30}$. Nie była to pierwsza wzmianka o prowizorach świeckich placówki opiekuńczej, wybieranych 13 grudnia w dzień św. Łucji spośród ławnika i rajcy. W 1339 r., gdy kasztelan krakowski Spycimir darował duchakom kamienicę koło szpitala, wspominał o roli świeckich w zarządzie placówką ${ }^{31}$. Następna wzmianka, tym razem o sporze klasztoru ze świeckimi prowizorami, pochodzi z $1395 \mathrm{r.}^{32}$, kolejna zaś z 1464 r., gdy rajcy krakowscy obniżyli o grzywnę należności płacone przez klasztor ${ }^{33}$. Prowizorzy zwani tutorami nie podlegali

54, 1988, s. 73-89; tenże Fundacja klasztoru karmelitów trzewiczkowych na Piasku w Krakowie, „Nasza Przeszłość” 63, 1983, s. 93-105).

${ }^{28}$ K. Antosiewicz, Zakon św. Ducha de Saxia..., s. 173.

${ }^{29}$ Archiwum Kurii Metropolitalnej w Krakowie (dalej: AKMK), AVCap., t. 43, Acta visitationum Ilustrissimi et Reverendissimi D. Iacobi Zadzik Episcopi Cracoviensis Ducis Severiensis, k. 310r-315v; tamże, Dekreta Reformationis szpitalow krakowskich z visitataciej czynionych Jakub Zadzik z łaski Bożej biskup krakowski książę siewierski..., k. 316v-317v; tamże, k. 316 v fragment dekretu Jerzego Radziwiłła z 1595 r.: Ex decretis reformationis Conventus et Hospitalis S. Spiritus Cracoviensis per Illum et Rendum D. Cardinalem Radziwilium Anno 1595 Prima February factis nonnulli Articuli excerpti L. Wachholz, dz. cyt., s. 28, 69; K. Antosiewicz, Zakon św. Ducha de Saxia..., s. 175. Duchacy zaciagnęli pożyczkę w 1531 r. na odbudowę klasztoru; AKMK, Acta officialia, t. 6, s. 603-607; K. Antosiewicz. Opieka nad dziećmi..., s. 37.

${ }^{30}$ „Aż iż osobliwej opatrzności Szpital S. Ducha potrzebujący znaleźliśmy, który $\mathrm{z}$ dawnej fundacjej swej wiele ubogich płci białogłowskich i dziatek porzuconych chowa tam nasze staranie principaliter obróciliśmy, znosząc się około tego z Pany Rajcy Miasta Krakowa, którzy za pewną zgodą od lat kilkadziesiąt z zakonnikami S. Ducha uczyniona prowizorami są tego Szpitala i z pośrodku siebie dwu do tąd obierali, wejrzawszy w pomienionych komisarzów naszych visitacyja, reformacyja, taką czyniemy i do executiej podajemy", AKMK, AVCap., t. 43, k. 310r, v.

${ }^{31}$ Kodeks dyplomatyczny miasta Krakowa, cz. 1-4, wyd. F. Piekosiński, Kraków 1889-1892, tu cz. 3, nr 378, s. 503: „quod Magister Hospitalis predicti pariter cum petitore infirmorum qui per Consules Civitatis eiusdem fuerit constitutus".

${ }^{32}$ Tamże, cz. 1, nr 82, s. 112: „Consules Civitatis Cracoviensis actores ex una et honarabiles religiosisque viros dominos magistrum Vitum et conventus monasterii Sancti Spiritus hospitalis de Cracovia, parte et altera”.

${ }^{33}$ Tamże, cz. 3, nr 462, s. 608; W. Męczyński, Prowizorowie szpitali w dawnej Polsce, Warszawa 1908. 
władzy prepozyta zakonnego stojacego na czele zgromadzenia, lecz miastu $^{34}$. Podobnie było zresztą w innych placówkach szpitalnych, np. św. Trójcy we Wrocławiu ${ }^{35}$. Ten podział władzy powodował nadużycia i spory między klasztorem a świeckimi, o czym zachowały się informacje $\mathrm{z}$ drugiej połowy XVI w.

Wówczas prepozytem, zwanym także magister praeceptor domus et hospitalis vulgo praepositus, mającym pieczę nad klasztorem i ogólną nad szpitalem, był Maciej Regiomontanus z Królewca, twórca zachowanego źródła ${ }^{36}$. Pełnił tę funkcję w latach 1570-1591, a do 1585 r. łączył ją z urzędem prowincjała wybieranego przez kapitułę ${ }^{37}$. Właśnie w tej drugiej roli prowadził spór z prowizorem Maciejem Urbanowiczem i mularzem Gabrielem Słońskim w latach 1573-1577, którego przedmiotem były ich zaniedbania względem stanu budynków szpitalnych: „niemocnica zła, trzeba inszą budować dla chorego ubóstwa”, „spustoszenie i pognojenie domów, izdeb, komnath, piwnic”, „gdy deszcz pada w szkole szpitalnej pełno wody”, a „na półpięćsta ubóstwa tylko pół korca grochu lub krup warzyć daja”. O nie najgorszym stanie budynków szpitalnych wspominał natomiast bp Filip Padniewski wizytujący duchaków w 1568 r. ${ }^{38}$ Wynikało to zapewne z faktu, że poprzednik Regiomontanusa, prepozyt Jan z Wiślicy ${ }^{39}$, przeprowadził remont szkoły dla dzieci - podrzutków i ubóstwa - będących pod opieką duchaków, i być może także innych zabudowań. Na poprawę warunków mieszkaniowych zarówno zakonników, jak i ubogich trzeba było czekać ponad pół wieku ${ }^{40}$. Nie wiadomo dokładnie, jak wyglądał kompleks budynków klasztornych i szpitalnych w XVI w. Jedyny opis zabudowań szpitala jest bardzo późny i pochodzi z wizytacji bp. Jana Lipskiego z 1738 r. ${ }^{41}$ W 1568 r. w szpitalu przebywało 280 osób chorych i ubogich oraz 80 dzieci,

${ }^{34} \mathrm{O}$ prowizorach zob. S. Piekarczyk, Poczqtki miejskiej opieki społecznej $w$ średniowiecznym mieście Krakowie, „Rocznik Krakowski” 32, 1952, nr 4, s. 97-140.

${ }^{35}$ M. Słoń, Szpitale..., s. 49, 53.

${ }^{36}$ BJ 6387 Rachunki.

${ }^{37}$ Tamże, k. 16, wspomina o wyborze na prepozyta: „Anno 1570 a feria secunda post Dominicam Conductus Pascha qua in hoc minus Praepositura electus sum”; K. Piekarski, Bibliographica w rachunkach duchaków krakowskich XVI wieku, „Marginalia” 1925, nr 5, s. 5-7, nie uwzględnił tego wpisu.

${ }^{38}$ AKMK, ACap. 1, Liber visitationis ecclesiarum in civitate ac dioecesi Cracoviensi Dei gratia episcopi Cracoviensis Philippi Padniewski, s. 17, 20, 73-75.

${ }^{39}$ S. Tomkowicz, dz. cyt., s. 50.

${ }^{40}$ Po inwazji wojsk szwedzkich, gdy budynki zostały niemalże doszczętnie zniszczone, pieniądze na odbudowę kompleksu przekazał bp Andrzej Trzebicki. Trwała ona ponad 20 lat (1657-1679); ANKrak., sygn. 3457, Wizytacja bp. Lipskiego; L. Wachholz, dz. cyt., s. 80 .

${ }^{41}$ ANKrak., rkps 3457, Visitatio externa et interna. 
z których większość stanowiły podrzutki ${ }^{42}$. Przez niedbalstwo prowizorów zaniechano jednak kształcenia w szkole chłopców ${ }^{43}$. Ostatecznie wyrok w sprawie zaniedbań świeckich prowizorów, którzy tylko jedna trzecią dochodów przeznaczali na szpital, a sami zabierali resztę, był korzystny dla klasztoru, uznano bowiem, że przez zły zarząd świeckich prowizorów straty klasztoru sięgnęły kilku tysięcy florenów. Urbanowicz musiał zapłacić $300 \mathrm{fl}$. kary, co zmusiło go do sprzedaży domu przy ul. Mikołajskiej, a miasto jako wyderkauf zapisało klasztorowi $1000 \mathrm{fl}$. na jednej z kamienic ${ }^{44}$. Kolejne procesy w latach 80 . XVI w. prepozyt Maciej wytoczył przedmieszczanom wielickim, którzy nie oddawali na potrzeby konwentu i szpitala drobiu, tak jak zapisano w dokumencie fundacyjnym, oraz przeciw egzekutorom testamentu dzierżawcy browaru św. Ducha Alberta Węgrzyna, a także poddanym w Krowodrzy. Te wszystkie również zakończyły się pomyślnie dla konwentu krakowskiego ${ }^{45}$. Po śmierci Regiomontanusa Zygmunt III Waza w 1595 r. wyznaczył komisję z wojewodą Mikołajem Zebrzydowskim na czele, która miała zbadać akta klasztorne oraz sprawy dotyczące zarządu szpitala. Ta stwierdziła, że prowizorzy świeccy nie dbali o ściaganie należności i dlatego stan szpitala był tak zły ${ }^{46}$.

Rękopis z lat 1570-1591 ma 40 kart o wymiarach 31,1 x 20,5 [i mniej] $\mathrm{cm}$ oprawionych $\mathrm{w}$ półskórek ${ }^{47}$. Nie dochował się w całości i jest zdefektowany - brakuje w nim kilku, a może kilkunastu kart w środku i na końcu. Świadczy o tym charakter zapisów. O defekcie stanowią wpisy $\mathrm{w}$ dwóch miejscach, gdzie brakuje kontynuacji tematycznej i chronologicznej. Pierwsze to lista należności wobec osób prywatnych - cyrografów (między kartami 2 i 2a oraz 2a i 3), drugie to końcowe karty w dziale Contributio, w którym zapisywano sumy przekazywane jako podatki i dziesięciny ze wsi i włości należących do klasztoru; tu narracja urywa się w $1583 \mathrm{r}$.

\footnotetext{
${ }^{42}$ AKMK, ACap. 1, Liber visitationis Padniewski, s. 57-59.

${ }^{43}$ Tamże, s. 73; S. Tomkowicz, dz. cyt., s. 52.

${ }^{44}$ Informacje pochodzą z kopiarza duchaków przechowywanego niegdyś w domu księży emerytów, obecnie zaginionego. Ostatni korzystał z niego w latach 80. XIX w. właśnie S. Tomkowicz (dz. cyt., s. 34).

${ }_{45}$ Tamże, s. 35, 39.

${ }^{46}$ L. Wachholz, dz. cyt., s. 78.

${ }^{47}$ BJ 6387 Rachunki; Inwentarz rękopisów Biblioteki Jagiellońskiej nr 6001-7000, cz. 1: $n r$ 6001-6500, oprac. A. Jałbrzykowska, J. Zathey, współ. Z. Łagodowa, J. Tyszkowska, Kraków 1962, s. 177. Karty sa popodklejane, a prawe ich strony najprawdopodobniej wtórnie powycinane, tak że tworza ,schodkowy skorowidz" z nazwami poszczególnych działów: Gregorio Ulanowski, Debita variis personibus soluta, Aedificia commonia, Mercem Familiae, Contributiones et (urwana część karty). Rękopis jest darem Kazimierza Piekarskiego z 22 VII 1925 r.
} 


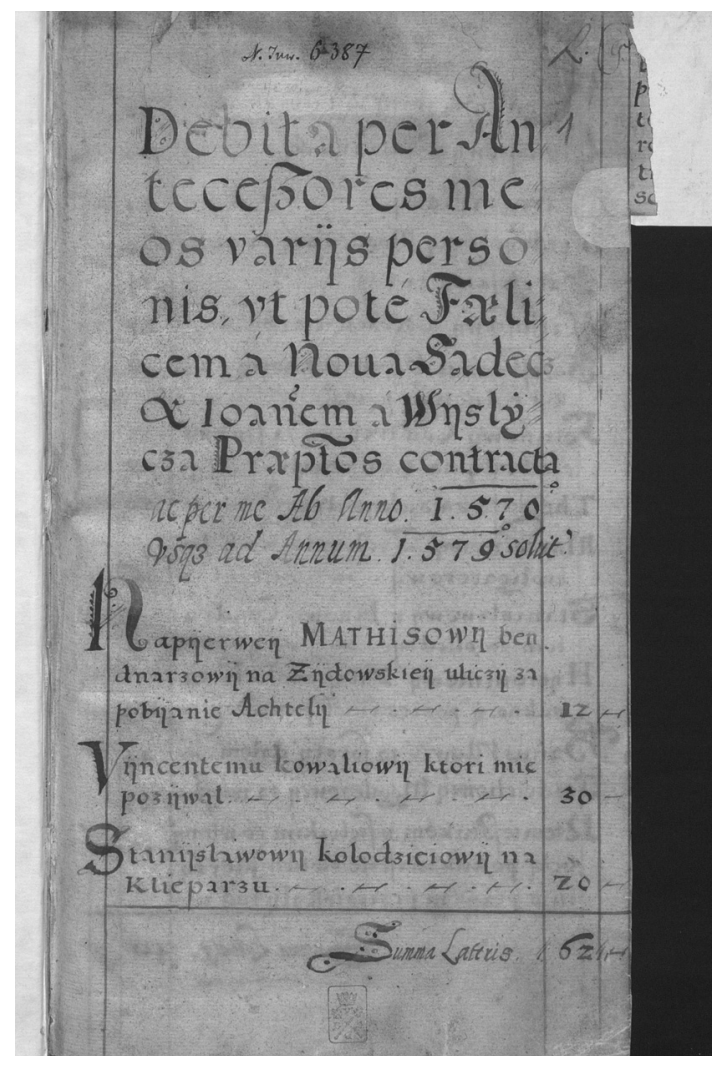

BJ 6387 Rachunki, III, k. 1r.

Autorem jest bezsprzecznie Regiomontanus, który pisze w pierwszej osobie liczby pojedynczej, a poza tym informuje o pracach wykonanych w należących do niego izbach. Używał przede wszystkim języka polskiego, ale także miejscami łaciny, w której spisywał wszystkie nagłówki - działy wydatków. Biorąc pod uwagę fakt, że regestr prowadziła osoba duchowna, jest rzeczą ciekawą dominacja języka polskiego nad łacina. Warto podkreślić, że inne rękopisy rachunkowe prowadzone $\mathrm{w}$ klasztorach $\mathrm{w}$ pierwszej połowie XVI w. pisano jednak głównie po łacinie ${ }^{48}$. Przełom, stopniowy, a nie radykalna zmiana, musiał nastapić $\mathrm{w}$ tym względzie w drugiej połowie tego stulecia, gdyż język narodowy jest również dominującym $\mathrm{w}$ rachunkach szpitala prowadzonych przez świeckich prepozytów z drugiej połowy XVI i początku XVII w. oraz

${ }^{48}$ M. Zdanek, Dochody dominikanów..., s. 259-260; tenże, Dochodowość klasztoru cystersów w Mogile w połowie XVI w. na podstawie inwentarza dóbr z lat 1560-1566, w: Klasztor $w$ gospodarce..., s. 257-274. 


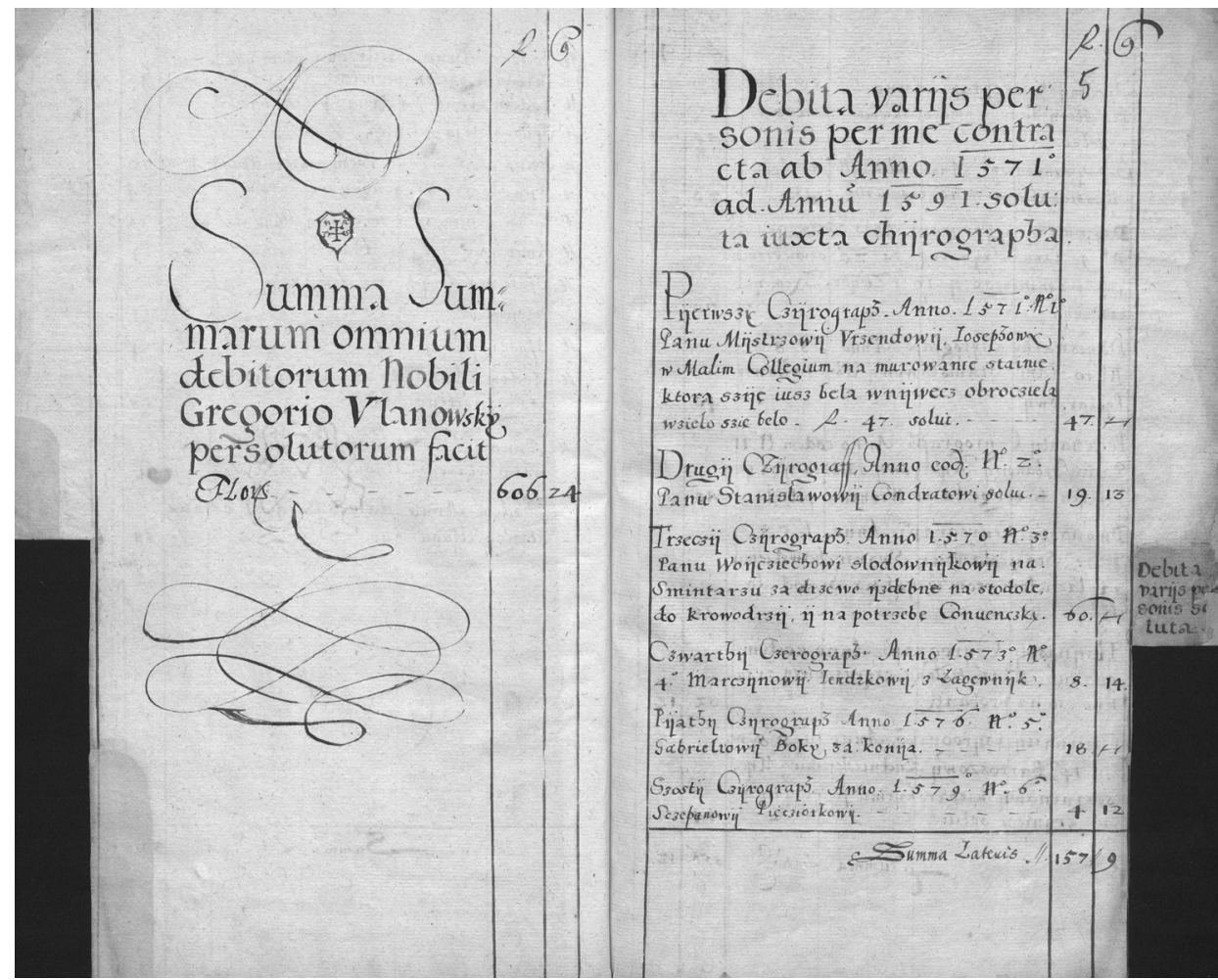

BJ 6387 Rachunki, III, k. 4v-5r.

w rachunkach innych zgromadzeń, np. klarysek sądeckich, począwszy od najstarszej księgi z 1602 r. ${ }^{49}$

$\mathrm{Na}$ karcie rachunków klasztornych (4v) znalazł się, kreślony ręka prepozyta Macieja, herb duchaków z charakterystycznym podwójnym krzyżem i literami w czterech rogach M.R.P.S. - Matthias Regiomontanus Praepositus Spiritus ${ }^{50}$. Na kartach pojawiają się też wpisy w pierwszej osobie liczby pojedynczej świadczące o autorze księgi, co należy do rzadkości w XV-XVI w., gdyż sporządzajaccy rejestry byli anonimowi i nie używali wpisów w pierwszej osobie ${ }^{51}$.

Każda karta rękopisu ma nakreślone linie tworzące rubryki: w pierwszej znajdują się informacje o osobie, która pobrała należność oraz wykonanej przez nią pracy, w drugiej - kwota we florenach, w trzeciej

${ }^{49}$ ANKrak., Akta miasta Krakowa, rkps 3397a, 3398, 3999, 3400 i n.; O.M. Przybyłowicz, Rachunki klasztorne jako źródto..., s. 200-201.

${ }^{50}$ BJ 6387 Rachunki, k. 4v.

${ }^{51}$ M. Słoń, Szpitale..., s. 56. 
zaś kwota w groszach. Ponieważ karty noszą ślady po ucięciu, można na niektórych stwierdzić wydzielenie czwartej rubryki, jednak tam gdzie ją zachowano nie stwierdziłam wpisów. Na większości kart na dole spisujący podawał zsumowaną kwotę wydatków, wyrażając to słowami: Summa Lateris ${ }^{52}$.

Informacje dotyczą wydatków na określone potrzeby klasztoru i usługi wykonywane przez różne osoby dla duchaków. Zapisano je najczęściej w skali rocznej, nie zaś kwartalnej ${ }^{53}$ czy tygodniowej bądź dziennej, co było najczęstsza praktyka przy prowadzeniu rachunków klasztornych wczesnej epoki nowożytnej, np. klarysek starosądeckich z lat 1602$-1604^{54}$, benedyktynów tynieckich z pierwszej połowy XVI w ${ }^{55}$ czy szpitala duchaków, pisanych w tymże stuleciu przez świeckich prowizorów ${ }^{56}$.

Taki zapis oznacza, że mamy więc do czynienia z czystopisem, rodzajem sumariusza, w którym w uporządkowany sposób, głównie chronologicznie, odnotowano wydatki i należności, na podstawie innych niezrachowanych notatek i zapisów. Podstawą rękopisu musiał być brudnopis bądź brudnopisy - luźne kartki, na których odnotowywano z większą szczegółowością wydatkowane pojedyncze kwoty ${ }^{57}$. Te informacje przenoszono następnie do jednej księgi, sumujac poszczególne kwoty. Zapewne większość transakcji sankcjonowano zapisem, nie zaś ustna umowa, o czym świadczy dość rozbudowana buchalteria klasztorna zachowana dla konwentów z terenu Europy Zachodniej ${ }^{58}$. Wydaje się, że rękopis powstał najprawdopodobniej na użytek prepozyta, nie stanowił

${ }^{52}$ BJ 6387 Rachunki. Brak zsumowania na kilku kartach między k. 30v a 40r.

${ }_{53}$ Tak u dominikanów; M. Zdanek, Dochody dominikanów..., s. 262.

${ }^{54}$ O.M. Przybyłowicz, Rachunki klasztorne jako źródto...

${ }^{55}$ M.T. Gronowski (Zwyczajny klasztor...) korzysta w badaniach nad składem konwentu z rachunków klasztornych z pierwszej połowy XVI w., przechowywanych również w Bibliotece Jagiellońskiej.

${ }^{56}$ ANKrak., Akta miasta Krakowa, rkps 3397a, Regestr wydawania i przyięcia na szpital św. Ducha tego to roku 1561; ANKrak., rkps Regestra szpitalne. Dochody i rozchody szpitala św. Ducha w Krakowie 1595-1596.

${ }^{57}$ M. Słoń, Szpitale..., s. 51-52, przedstawił zachowaną dokumentację rachunkową wrocławskich szpitali w średniowieczu, konstatując, że większość z nich jest czystopisami noszącymi ślady korzystania $\mathrm{z}$ brudnopisów.

${ }^{58} \mathrm{Na}$ przykład rachunki kanoników regularnych w Neuburgu, spisywane systematycznie od XIV w., odnoszą się do poszczególnych urzędów, instytucji klasztornych, w końcu różnorodnych sfer działalności: rachunki opata, najwyższego ekonoma, kustosza, budowlane, kuchni i piekarni, winnic, leśniczego oraz przyklasztornego szpitala; F. Röhrig, Die materielle Kultur des Chorherrenstiftes Klosterneuburg unter besonderer Berücksichtigung der Aussage von Rechnungsbüchern, w: Klösterliche Sachkultur des Spätmittelalters, Internationaler Kongress Krems an der Donau 18-21 IX 1978, Wien 1980, s. 217-224. 
zaś narzędzia kontroli władz zwierzchnich zakonu (sam Maciej był przecież prowincjałem) ani świeckich, którzy do zarządu wspólnotą nie mieli praw. Po objęciu rządów prepozyt chciał zrewidować stan finansów wspólnoty po poprzedniku, a następnie systematyzował, najczęściej w skali rocznej, wydatki z własnej, długiej kadencji,

Rękopis zawiera należności (k. 1r-2v) wobec różnych osób, które powstały za czasów rządów poprzedników Regiomontanusa: prepozytów Feliksa z Nowego Sącza i Jana z Wiślicy. Maciej spłacał je w latach 1570-1579, więc zapewne dlatego zostały wciaggnięte do niniejszej księgi ${ }^{59}$. Na kolejnych (k. 3r-4v) odnotował zobowiązania bieżące wobec Grzegorza Ulanowskiego, należności (k. 5r-11r) z lat 1571-1591 według listy cyrografów ${ }^{60}$. Między kartami $2 \mathrm{v}-3 \mathrm{r}$ znalazła się karta (oznaczona jako 2a-2b), na której odnotowano listę zobowiązań duchaków wobec kolejnych osób prywatnych, tzw. cyrografy z lat 1582-1585. Trudno ustalić, czy jest to fragment innego rękopisu (rozmiar kart i charakter pisma jest taki sam). Brakuje pierwszych ośmiu pozycji zobowiązań, a zapisem pierwszym jest informacja o cyrografie $\mathrm{z}$ numerem dziewięć. Od k. 6r rozpoczynają się właściwe wydatki Macieja z 20 lat jego rzadów (1571-1591). Znalazły się tu wydatki jednorazowe, a wśród nich wydzielono rachunki budowlane (k. 12r-14r), co było częsta praktyką postępowania w buchalterii klasztornej i szpitalnej ${ }^{61}$, oraz stałe. Do tych ostatnich należy finansowanie członków familii klasztornej księży i czeladzi (k. 16r-36v w skali rocznej) ${ }^{62}$. Ostatnie karty to zobowiązania dziesięcinne i inne należności klasztoru z pozakrakowskich majątków konwentu (k. 37r-40v).

Księga przynosi informacje sensu stricto ekonomiczne, tj. o wysokości wydatków, przede wszystkim na potrzeby zgromadzenia, a w niektórych przypadkach szpitala i przyklasztornej szkoły, choć te obydwie instytucje miały oddzielne wydatki i księgi rachunkowe, o czym

${ }^{59}$ BJ 6387 Rachunki, k. 1: „Debita per antecessores meos variis personis, ut pote a Faelicem a Nova Sadecz et Joannem a Wyslycza preapositos contracta nunc per me ab anno 1570 usque ad annum 1579 solvit”.

${ }^{60}$ Tamże, k. 5r: „Debita variis personie per me contracta ab Anno 1571 ad Annum 1591 soluta iuxta chyrographa”.

${ }^{61}$ O.M. Przybyłowicz, Rachunki klasztorne jako źródto..., s. 201. W rachunkach starosądeckich klarysek z 1602-1604 wyszczególniono na kilku kartach: „Regestra wydawania pieniędzy na rozmaite rzemiemski [sic] i budowanie klasztoru...”; M. Słoń (Szpitale..., s. 50) uważa nawet, że rachunki budowlane stanowiły osobną kategorię ksiag prowadzonych w szpitalach średniowiecznych.

${ }^{62}$ Także u klarysek starosądeckich stałe wypłaty dla członków familii oraz pensje dla sióstr, płacone w dwóch ratach: co roku na św. Jana i św. Marcina; O.M. Przybyłowicz, Rachunki klasztorne jako źródto..., s. 204, 211-213. 
przekonuje zarówno wyżej wymieniona kolekcja rękopisów w krakowskim Archiwum Narodowym, jak i literatura przedmiotu poświęcona szpitalom $^{63}$. Nie znamy relacji ekonomicznych i finansowych między majątkiem i dochodami klasztoru oraz szpitala, a bez przebadania rachunków placówki opiekuńczej nie sposób odpowiedzieć na pytanie o finansowe zobowiązania bądź niezależność klasztoru względem szpitala. Najprawdopodobniej istniała pewnego rodzaju symbioza wydatków na klasztor i kościół zakonników oraz budynki przeznaczone dla ich podopiecznych. Jej korzenie sięgaja co najmniej początku XIV w., o czym świadczy dokument wspominanego już kasztelana krakowskiego Spycimira, który obdarował duchaków kamienica, zaznaczając, że dochód $\mathrm{z}$ niej $\mathrm{w}$ połowie musi być przeznaczany na potrzeby szpitala, a w połowie dla zakonników, których zobowiązał do remontowania budynku ${ }^{64}$. Podkreśla ją także instrukcja bp. Zadzika z 1638 r., zamieszczona w wizytacji dla szpitala duchaków: „Tenże X Proboszcz ma często szpital nawiedzać patrząc i uważać in quo statu są ubodzy, jaki kędy defekt czego któremu potrzebnego niedostaje i o tym dawać znać prowizorom i z niemi około opatrzenia i zabierzenia defektów in fraterna charitate tego się domagając co prowenta szpitalne znieść moga, gdyż nad intratę pociagać nic inszego nie jest tylko do confusiej occasią dawać, kommunikowal"65.

Druga grupę informacji stanowia dane o środowisku społecznym i więziach klasztoru z miastem oraz jego mieszkańcami, przede wszystkimi tymi, którzy wykonywali usługi na rzecz wspólnoty, ale i udzielali konwentowi pożyczek oraz finansowego wsparcia na określone cele.

Charakter wpisów - jest to jedynie księga expensów, a nie dochodów - perceptów, uniemożliwia przeprowadzenie analizy stanu klasztornych finansów, dokonania bilansu budżetu. Niemożliwa jest także ocena dochodowości gospodarki duchaków, tak jak uczynił to Maciej Zdanek w odniesieniu do dominikanów krakowskich w XVI stuleciu, dysponujący zarówno Liber expositorum, jak i Liber perceptorum z zazębiajacego się chronologicznie okresu, czy też Dominika Burdzy pisząca o klasztorach dominikańskich w Sandomierzu w XVIII stuleciu, mająca również do dyspozycji oba typy ksiag rachunkowych ${ }^{66}$. W tym przypadku nie sposób podać rocznych wydatków, gdyż nie ma żadnego roku, dla którego zachowały się dane o wszystkich kategoriach wydat-

\footnotetext{
${ }^{63}$ M. Słoń, Szpitale..., s. 44, 46-50.

${ }^{64}$ Zob. przyp. 28; Kodeks dyplomatyczny miasta Krakowa..., cz. 3, nr 378.

${ }^{65}$ AKMK, AVCap., t. 43, k. 311v.

${ }^{66}$ D. Burdzy, „Percepta et expensa”..., s. 319-332.
} 
kowanych pieniędzy. Dodatkowo część wpisów dotyczących sum na jednorazowe zakupy nie została przypisana do konkretnego roku, jak np. na k. 6r, na której po 17 cyrografie zapisano bez daty: „Panu Mychalowskiemu pisarzowi oświęcimskiemu zapłaciłem ad rationem długu fl. 50 co mi beł pożyczeł na actia z Byechowskim w Lublinie”, po czym dopiero kolejny wpis pod spodem informuje o dacie zapłaty z $1573 \mathrm{r}^{67}$

Wiadomości zaprezentowane poniżej na podstawie analizy źródła to jedynie wycinek realiów życia zgromadzenia, ukazujący jednak sposób funkcjonowania klasztoru w środowisku miejskim, świat rzeczy materialnych i relacji międzyludzkich. Regiomontanus jawi się w rachunkach jako osoba prężna, aktywna, dbająca o dobro klasztoru.

Rejestry cyrografów, czyli pisemnych zobowiąań duchaków wobec osób prywatnych, dotyczyły stosunkowo dużych kwot - przeważnie kilkudziesięciu do nawet 220 florenów (tylko trzy razy poniżej 10). Zapisy świadczą o tym, że klasztor zaciagał pożyczki i nie dysponował nadwyżkami, które pozwoliłyby na regulowanie wszelkich, zazwyczaj nadzwyczajnych należności od razu. Pierwszy z wpisów, zawarty na mocno uszkodzonych kartach o liczbie porządkowej 9, pochodzi z 1582 r. i opiewa na kwotę $40 \mathrm{fl}$. Zaciagnięcie pożyczki wiązało się z wyprawieniem duchaka, księdza Wojciecha Smoleńskiego na probostwo kaliskie. Dziesiąty dokument, także z 1582 r., to kwota $30 \mathrm{fl}$. przeznaczona na sprawy toczone przed trybunałem koronnym, jedenasty zaś, z tego samego roku, to $20 \mathrm{fl}$. na sąd trybunalski oraz zapłacenie dziesięciny z Wronina ${ }^{68}$. Kolejne dwa, z 1583 r., wiązały się z zakupem pszenicy miary proszowskiej oraz słodu - w sumie za $60 \mathrm{fl} .{ }^{69}$ Czternasty cyrograf z 1585 r. „od księdza proboszcza telko samego na wzięcie złotych sześć i polskie $6 " 70$. Druga część cyrografów rozpoczyna się na k. 5r, począwszy od 1570 lub $1571 \mathrm{r}^{71}$, i kończy się w 1589 r., choć w nagłówku widnieja jeszcze dwa lata. Znalazły się tu kwoty pożyczek przeznaczone na prace remontowe $\mathrm{w}$ budynkach gospodarczych oraz $\mathrm{w}$ klasztorze, a także zobowiązania wobec osób prywatnych, czasami bez wyszczególnienia, na co przeznaczono pieniądze ${ }^{72}$.

${ }^{67}$ BJ 6387 Rachunki, k. 6r.

${ }^{68}$ Tamże, k. 2a.

${ }^{69}$ Tamże, k. 3b.

70 Tamże, k. 3b, może Smolińskiego?

${ }^{71}$ Tamże, k. 5r. Pierwsze dwa z 1571 r., trzeci z 1570 r. Zapis nagłówka brzmi: „ab Anno 1571 ad Annom 1591". Zapisy chronologicznie rozpoczynają się od $1571 \mathrm{r}$. Po dwóch wpisach z tego roku następują w 1570 r., a potem 1573 r. Prawdopodobna jest to pomyłka Regiomontanusa - umowa mogła dotyczyć 1572 r.

${ }^{72}$ Tamże, k. 5r: Marcinowi Iendzkowi, Szczepanowi Pięcziorkowi. 
Tabela 1. Cyrografy w latach 1570-1589

\begin{tabular}{c|c|c|c}
\hline \multirow{2}{*}{ Rok } & \multirow{2}{*}{ Liczba cyrografów } & \multicolumn{2}{|c}{ Wartość cyrografów } \\
\cline { 3 - 4 } & & floreny & grosze \\
\hline $1570^{73}$ & 2 & 60 & 13 \\
\hline 1571 & 1 & 66 & 14 \\
\hline 1573 & 1 & 8 & 12 \\
\hline 1576 & 1 & 18 & \\
\hline 1579 & 3 & 4 & 12 \\
\hline 1580 & 5 & 130 & \\
\hline 1582 & 4 & 122 & \\
\hline 1583 & 2 & 50 & \\
\hline 1585 & 1 & 220 & \\
\hline 1588 & 3 & 47 & \\
\hline 1589 & 24 & 936 & \\
\hline Razem & 2 & & \\
\hline
\end{tabular}

Źródło: BJ 6387 Rachunki, k. 2a-2b, 5r-6r.

Przed listą cyrografów prepozyt spisał należności wobec Grzegorza Ulanowskiego z lata 1570-1580, które związane były z zakupem i spławem drewna na budowę spiżarni w Krowodrzy, stajni i oparkanienia tychże oraz z zakupem drewna na opalanie ${ }^{74}$. Prace inwestycyjne były spore, skoro Maciej zdecydował się na zaciagnięcie pożyczki w wysokości 500 fl. na zakup materiału budowlanego. Należność oddawał Ulanowskiemu w ratach do 1580 r., gdyż kwota całkowita za zakupione materiały oraz pożyczka Grzegorza wyniosła $606 \mathrm{fl}$. i $24 \mathrm{gr}$, jak wynika z zapisu na osobnej karcie. W rachunku końcowym nie uwzględnił Regiomontanus wydatków zapisanych na k. 3r i 3v, wpisanych nie w rubryki za floreny i grosze, lecz w pierwszej rubryce od lewej strony, informującej o należnościach za poszczególne towary i usługi dla konkretnych osób ${ }^{75}$.

Wydatki można podzielić na stałe, często się powtarzajace i jednorazowe. Do tych pierwszych oprócz wyżej wymienionych pensji dla członków familii klasztornej zaliczyć należy powinności dawane na łaźnię,

\footnotetext{
${ }^{73}$ Zob. przyp. 59.

${ }^{74}$ BJ 6387 Rachunki, k. 4r -5v.

${ }^{75}$ Tamże, k. $3 \mathrm{r}-36 \mathrm{fl}, \mathrm{k} .3 \mathrm{v}$ w sumie jest $173 \mathrm{fl}$, a jedna pozycja nieczytelna ze względu na plamę tuszu, przy pozycji za cztery kopy krokwi po 18 łokci. Tylko 24 gr zapłacono włóczkom za wykładanie.
} 
sprawy sądowe - trybunał oraz należności dziesięcinne i inne zobowiazania płacone z dóbr klasztoru. Do drugich - pozycje przeznaczane na usługi rzemieślników, zakup wyżywienia, inne sprawy sądowe (nie trybunał) i inwestycje budowlane. Jednorazowe to lista kilkunastu niepowtarzających się wypłat na różnorodne cele.

Pierwsza lista wydatków i dawnych zobowiązań duchaków wobec osób prywatnych za lata 1570-1579, czyli sprzed rządów Macieja, daje już wgląd w społeczne struktury dużego ośrodka miejskiego, jakim był Kraków, związki konwentu z przedstawicielami rzemiosł oraz zawiera pewne informacje socjotopograficzne. Przy imionach bądź nazwiskach notował prepozyt niekiedy ulicę lub dzielnicę, z której pochodziły osoby wchodzace $\mathrm{w}$ relacje finansowo-ekonomiczne z klasztorem. Sa na tej liście bednarze, m.in. imiennie wymieniony Mathis z ul. Żydowskiej ${ }^{76}$, kołodzieje, m.in. znany z imienia Stanisław z Kleparza $^{77}$, kowale, m.in. Piotr Niemiec ${ }^{78}$, stelmachowie, ślusarze, garncarze, mieszczanie - dostawcy produktów, głównie mięsa, np. Grodecki z Kleparza ${ }^{79}$. W 1585 r. prepozyt oddawał natomiast zaciagnięty dług Bartoszowi Rudnickiemu, mieszczaninowi kleparskiemu ${ }^{80}$. Nie sposób ich zidentyfikować wyłącznie na podstawie jednej wzmianki. Zachowane dane pozwalają na ostrożne sformułowanie, że mieszczanie wchodzący w relacje z klasztorem pochodzili najczęściej z Kleparza, położonego w pobliżu klasztoru, lecz poza murami miejskimi. Raz wymieniono rzemieślnika z Kazimierza. Związki z Kleparzem potwierdza też dokument pergaminowy z 1596 r. następcy Macieja - Jana Piotrowskiego, który był nie tylko prepozytem kościoła św. Krzyża, ale też generalnym przełożonym (prowincjałem) klasztorów i szpitali św. Ducha w Polsce. W imieniu konwentu wydzierżawił on cechowi powroźników kleparskich grunt za Kleparzem, potrzebny im do uprawiania rzemiosła, za roczny czynsz w wysokości grzywny i $24 \mathrm{gr}^{81}$.

$\mathrm{O}$ kolejnych osobach majacych relacje $\mathrm{z}$ duchakami informacje przynoszą inne źródła. Chodzi tu o introligatorów i drukarzy krakowskich. Marcinowi Zachariaszowi należącemu do cechu introligatorów ${ }^{82}$ duchak

\footnotetext{
76 Tamże, k. 1r.

77 Tamże.

${ }^{78}$ Tamże, k. 6v.

79 Tamże, k. 2r.

${ }^{80}$ Tamże, k. 6r.

${ }^{81}$ W ANKrak., podaję za K. Antosiewicz, Zachowane źródta..., dok. nr 21.

${ }^{82}$ Marcin potwierdzał statuty cechy introligatorów w 1657 r.; Monumenta Polonia Typographica XV et XVI saeculorum, t. 1,wyd. J. Ptaśnik, Leopoli 1922, nr 606; K. Piekarski, dz. cyt., s. 5.
} 
zapłacił 6 fl., a drukarzowi Matyszowi Zybeinecherowi 50 fl. za oprawę gramatyki napisanej przez współbrata Bazeusza ze Szczebrzeszyna, tegoż samego, który był autorem dziejów zakonu ${ }^{83}$. Prepozyt uregulował też zobowiązania wobec rzemieślników: „Rzemieśnikom wszeliakim co winny beły po kilkanaście zlotych, którzy mie prawem przyciskali rad nie rad musiałem zapłacić" ${ }^{84}$. Suma należności Regiomontanusa wyniosła według jego wyliczeń $1113 \mathrm{fl}$. i 3 gr. Zsumowanie pozycji dało jednak kwotę nieco niższą - 1112 fl. i 18 gr. Różnica wynika z niemożności odczytu liczby groszy przy wyżej podanej ogólnej kwocie długów wobec wszystkich rzemieślników - 118 fl., gdyż w miejscu kolumny groszy karta rękopisu jest uszkodzona - oberwana została jej dolna częśśc5.

Na liście expensów ogólnych oraz cyrografów prepozyta Macieja za lata 1571-1591 znalazło się wiele pozycji związanych z inwestycjami budowlanymi przeprowadzanymi przez Regiomontanusa w klasztorze, kościele, kompleksie budynków gospodarczych duchaków, ale także w szkole i szpitalu, co pokazuje pewne zobowiązania konwentu wobec podległych mu budynków. Zapłacono m.in. mistrzowi Józefowi z Małego Collegium za zmurowanie stajni ${ }^{86}$, kowalowi Piotrowi Niemcowi z Kleparza za prace wykonane w szkole ${ }^{87}$, Dorocie Mogielczowej za „restauratione stabuli, nec non scholam restauravi per se Anno 1570 unde etiam et via quam antiquitus corrupta est alias bruk de novo erexi”, za kamień do komina do izby czeladnej ${ }^{88}$, za wapno i cegłę na kaplicę Hipolitowi Włochowi, za stoszek kamienny oraz dachówkę, a Kasperkowi Miecznikowi z Kazimierza „za orczlie do tejże kaplicze, bo trzy ściany z gruntu wywiedzione" ${ }^{89}$, za prace w chórze kościoła św. Ducha ${ }^{90}$, mularzowi za prace kamieniarskie $\mathrm{w}$ izbie Macieja ${ }^{91}$. Ponadto dał on pieniądze od robienia „grobów 3. w wielkim kościele: jeden w kurze u pulpita, a drugi pralatowi staremu Ioanni a Wyslicza ante altare

${ }^{83}$ BJ 6387 Rachunki, k. 2r. Gramatyka była w formacie in octavo, liczyła 192 karty, czyli 24 arkusze, a więc jedna składka kosztowała 2 fl.; K. Piekarski, dz. cyt., s. 6.

${ }^{84}$ BJ 6387 Rachunki, k. 2r.

${ }^{85}$ Tamże, k. 2v. Kwota niemała 118 fl., grosze nieczytelne, byłoby to więc 15 gr.

${ }^{86}$ Tamże, k. 5r. Nie określono jej lokalizacji.

${ }_{87}$ Tamże, k. 6r.

${ }_{88}$ Tamże, k. 7r.

${ }^{89}$ Tamże, k. 7v. Owe orczlie, czyli łupane, nieociosane kamienie; Stownik polszczyzny XVI wieku, t. 22, Wrocław-Warszawa-Kraków 1994, s. 75, orcel - „pro lapidibus quos vulgo orczle vocant".

${ }^{90}$ BJ 6387 Rachunki, 8r: „a tergo scholam S. Spiritus manenti ab aedificio loci private".

${ }^{91}$ Tamże, k. 9r. 
Corporis Christi, a trzeci podle niego mnie samemu"92. Wielokrotnie przeznaczał też niemałe kwoty na zakup materiałów budowlanych: drewna ${ }^{93}$, tarcic, gontów, gwoździ „i innego żelaza” potrzebnego przy przeprowadzaniu remontów, nie wiadomo, czy tylko w klasztorze i kościele, czy także w budynkach szpitalnych i szkole ${ }^{94}$. Z dokumentu innowacyjnego bp. Piotra Tomickiego wynika, że w kompleksie budynków klasztorno-szpitalnych znajdowała się także szkoła, dom administracyjny prepozyta, łaźnia, ogród, stajnia oraz trzy browary ${ }^{95}$.

Tabela 2. Wydatki na remonty i inwestycje budowlane oraz materiały temu służące w wydatkach ogólnych i cyrografach

\begin{tabular}{c|l|c|c}
\hline \multirow{2}{*}{ Rok } & & \multicolumn{1}{c|}{ Cel } & \multicolumn{2}{c}{ Wartość } \\
\cline { 3 - 4 } & & floreny & grosze \\
\hline 1571 & drewno, inne materiały na budowę, m.in. spiżarni w Kro- & 40 & 24 \\
& wodrzy & & \\
\hline 1571 & zmurowanie stajni przez mistrza & 57 & \\
\hline 1571 & tarcice do wrót konwentu w Krowodrzy & 5 & \\
\hline 1572 & tarcice do wrót konwentu w Krowodrzy & 73 & \\
\hline 1573 & drewno i materiały budowlane & 60 & \\
\hline 1573 & kamień i orczlie oraz robota murarska & 90 & \\
\hline 1574 & drewno i materiały budowlane & 160 & \\
\hline 1575 & drewno i materiały budowlane & 76 & \\
\hline 1576 & drewno i materiały budowlane & 30 & \\
\hline 1577 & drewno i materiały budowlane & 60 & \\
\hline 1578 & drewno i materiały budowlane & 90 & \\
\hline 1579 & drewno i materiały budowlane & 100 & \\
\hline 1580 & drewno i materiały budowlane & 6 & \\
\hline 1590 & żelazo & 10 & \\
\hline 1591 & drewno & 852 & 24 \\
\hline Suma & & & \\
\hline
\end{tabular}

${ }_{92}$ Tamże, k. 8v. Także znanemu Kacperkowi z Kazimierza za kamień i od komina cieśli lepiarzowi w browarze.

${ }_{93}$ Tamże, np. k. 8v: „Paniei Annie Mathuszowei pro lignis ad necessitatem conventus” - 40 fl., „Andrea Caldeatori in platea S. Floriani za pleth drew do konwentu” 30 fl., „Paniei Adamowej Kowaliowej za drwa” - 20 fl.

${ }_{94}$ Tamże, k. 5r-11r. Nie określał często, do czego było potrzebne, ale niektóre sa precyzyjne: k. 6r, że tarcice potrzebne do wrót konwenckich i do Krowodrzy, a więc klasztornej wsi, oraz na trumny.

${ }^{95}$ S. Tomkowicz, dz. cyt., s. 55; K. Antosiewicz, Opieka nad dziećmi..., s. 39. 


\begin{tabular}{c|l|r|r}
\hline Bez daty & orczlie & 14 & \\
rocznej & drewno & 48 & \\
& kamien do komina do izby czeladzi & 10 & \\
& wapno i cegła do remontu kaplicy & 80 & \\
& orczlie & 10 & 20 \\
& stoszek kamienny & 16 & \\
& gonty & 16 & \\
& remont budynku na tyłach chóru kościoła św. Ducha & 25 & \\
& zmurowanie grobów wościele & 20 & \\
& kamienie na murowanie & 10 & \\
& cieśli od komina & 12 & \\
& roboty murarskie w izbie Macieja & & \\
Suma & & 411 & 20 \\
\hline Suma & & $\mathbf{1 2 6 3}$ & $\mathbf{4 4}$ \\
całko- & & & \\
wita & & & \\
\hline
\end{tabular}

Źródło: BJ 6387 Rachunki, k. 1-11r, 2a-2b.

Osobno wydzielił natomiast prepozyt wydatki na poważniejsze inwestycje budowalne i remonty: Aedificia commonia tam denuo ex aedificata per me quam etiam restaurata ${ }^{96}$, które pochłonęły ponad $4500 \mathrm{fl}$. $\mathrm{w}$ okresie 20 lat. Sa to szczegółowe zapisy dotyczące prac w klasztorze oraz w innych budynkach, we wsiach, folwarkach i gruntach znajdujących się w dobrach klasztoru. Rozpoczął inwestycje w 1571 r., gdy polecił wystawienie wrót i wybudowanie muru: „począwszy od słodowni aż do łaźni”, który się uprzednio obalił, ponadto wystawił dwie stajnie i browar z kominem glinianym ${ }^{97}$. Marcin Kozioł, który „wyrobił” staw we Wroninie, otrzymał zapłatę nie tylko w pieniądzu, ale i naturaliach: zboża 10 korców miary proszowskiej, dwa korce grochu, tatarki i krup jęczmiennych, garnek masła, dwie kopy sera, dwa połcie mięsa i jedno sadło oraz trzy achtele piwa ${ }^{98}$. Kolejne inwestycje Regiomontanus przeprowadził we wsi duchaków - Kurdwanowie ${ }^{99}$. W $1572 \mathrm{r}$. wystawił natomiast w Krakowie kaplicę i zasklepił „dwa groby sklepiste jeden dla braci, a drugi dla sióstr zakonnych, którem z gruntu wywiódł murem i zasklepieł"100. Zadbał także o cloaca commonis, która „dał oprawić znowu i przelać”101. Około kościoła św. Ducha, czyli szpitalnego, postawiono sześć filarów, a „na pół trzecia łokcia wzwyż wiazania”. Zbudował też studnię przy browarze i druga przy łaźni, gdzie

\footnotetext{
${ }^{96}$ BJ 6387 Rachunki, k. 12r-14v.

${ }^{97}$ Tamże, k. 12r.

98 Tamże.

99 Tamże, k. 12v, m.in. kopanie przekopów.

100 Tamże.

101 Tamże.
} 
była poprzednio, ale po tym jak się zawaliła prawie nie było widać miejsca, w którym stała ${ }^{102}$. Odnowił izbę czeladna, będąca bez okien i pieca, w której z powodu fatalnego stanu wnętrza trzymano wcześniej tylko kury i gęsi ${ }^{103}$. W 1577 r. za naprawę łaźni wewnętrznej, tj. klasztornej, sprawienie nowej panwi i wystawienie pieca oraz izdebki, najprawdopodobniej przy tejże łaźni, zapłacił $200 \mathrm{fl}{ }^{104}$ Podczas budowy młyna kazał wykopać dwa stawy, na co wydatkowano nie tylko pieniadze, ale naturalia: leguminy oraz sukno ${ }^{105}$. W jego mieszkaniu znajdującym się, jak to określił, na górze, uczyniono „olmarie lany z dwiema ladamy, także dał powliec tram, bo się beli zagieli tak w izbie w sieni, w komacie"106. Almarie z dwiema ladami wskazuja, że były to raczej skrzynie niż szafy ${ }^{107}$. Imponujacych rozmiarów były inwestycje $\mathrm{w}$ folwarku Krowodrzy (400 fl.), które objęły budowę spiżarni do sypania zboża, odbudowę zawalonej stodoły, wystawienie obór i chlewów, których wcześniej nie było, domu, studni, oparkanienie całej posiadłości duchaków. Znaczący udział wydatków budowlanych był istotą działalności nie tylko klasztornej, gdyż jak pisała Małgorzata Borkowska: ,jak nie okna to schody, jak nie gonty to dach, to nowy ołtarz. I tak żyło się na nieustannej budowie, a przynajmniej w nieustannym remoncie"108, ale i szpitali, o czym świadczy np. zestawienie rachunków tych placówek z Liège ${ }^{109}$.

Ciekawe, że do tej grupy expensów prepozyt wpisał wydatki przeznaczone na zakup ksiag liturgicznych: graduał i antyfonarz wielki z pergaminowymi kartami. Pierwszą z nich zamówił u księdza zakrystianina (w źródle określonego już jako nieboszczyk) kościoła NMP w Krakowie. W zamian za co Maciej „płaz mu na ogród wymierzeł”. Była to najprawdopodobniej umowa, mówiąc współczesnym językiem, barterowa, gdyż w rubryce nie zapisano żadnej kwoty. Druga księga była bardzo cenna, skoro dał za nią 100 fl. ${ }^{110}$

102 Tamże.

103 Tamże.

104 Tamże, k. 13r.

105 Tamże, 86 fl.

106 Tamże, k. 13v.

${ }^{107}$ Stownik polszczyzny XVI wieku, t. 21, Wrocław-Kraków-Warszawa, 1992, s. 322, 323.

${ }^{108}$ M. Borkowska, Życie codzienne polskich klasztorów żeńskich $w$ XVII-XVIII $w$., Warszawa 1996, s. 100-101.

${ }^{109} \mathrm{P}$. de Spiegeler, Les hôpitaux et l'assistance á Liège (Xe-XVe siécles). Aspects institutionelles et sociaux, Paris 1987, s. 195 n., za: M. Słoń, Szpitale..., s. 20.

${ }^{110}$ BJ 6387 Rachunki, k. 13v, było to $100 \mathrm{fl}$. 
Tabela 3. Wydatki na inwestycje budowalne i remontowe wyszczególnione w rękopisie w osobnym dziale przez samego prepozyta

\begin{tabular}{|c|c|c|c|}
\hline \multirow{2}{*}{ Rok } & \multirow{2}{*}{ Cel } & \multicolumn{2}{|c|}{ Wartość } \\
\hline & & floreny & grosze \\
\hline 1571 & budowa wrót i muru na terenie klasztoru & 600 & \\
\hline 1571 & wykopanie stawu we Wroninie & 47 & \\
\hline 1571 & wykopanie stawu w Kurdwanowie & 50 & \\
\hline 1572 & zbudowanie kaplicy z grobami dla braci i sióstr & 900 & \\
\hline 1572 & poprawa kloaki & 60 & \\
\hline 1572 & wzmocnienie filarami kościoła św. Ducha & 800 & \\
\hline 1572 & budowa studni, browaru, łaźni & 70 & \\
\hline 1572 & naprawa izby czeladnej & 50 & \\
\hline 1573 & $\begin{array}{l}\text { budowa izdebki nad spiżarnią we Wroninie, } \\
\text { oparkanienie obór i stodół tamże }\end{array}$ & 70 & \\
\hline 1573 & $\begin{array}{l}\text { budowa studni w folwarku we Wroninie i drugiej } \\
\text { w tejże wsi }\end{array}$ & 280 & \\
\hline 1577 & $\begin{array}{l}\text { naprawa łaźni w klasztorze i wystawienie izdebki } \\
\text { z piecem }\end{array}$ & 200 & \\
\hline 1577 & wykopanie dwóch stawów (bez podania miejsca) & 86 & \\
\hline 1578 & budowa organów w kościele św. Ducha & 200 & \\
\hline 1580 & renowacja organów w wielkim kościele ('św. Krzyża?) & 150 & \\
\hline $1578-1591$ & $\begin{array}{l}\text { na budowę i utrzymanie słodowni wszystkich } \\
\text { i domków }\end{array}$ & 270 & 18 \\
\hline 1578 & remont w izbie prepozyta & 70 & \\
\hline $\begin{array}{l}\text { bez daty } \\
\text { (między } 1578 \\
\text { a 1590) }\end{array}$ & $\begin{array}{l}\text { w Krowodrzy remont stodół, budowa spiżarni, obór, } \\
\text { chlewów, studni, oparkanienie folwarku }\end{array}$ & 400 & \\
\hline $\begin{array}{l}\text { bez daty } \\
\text { (między } 1578 \\
\text { a 1590) }\end{array}$ & $\begin{array}{l}\text { budowa stajni w Wieliczce, oparkanienie i wystawie- } \\
\text { nie domu tamże }\end{array}$ & 200 & \\
\hline 1591 & poprawienie wychodu & 30 & \\
\hline 1591 & wybieranie studni i łaźni & 49 & \\
\hline Suma & & 4582 & $18^{111}$ \\
\hline
\end{tabular}

Źródło: BJ 6387 Rachunki, k. 12r-14r.

W kategorii wydatków częstych, choć nieregularnych, znalazła się żywność i piwo. Spośród produktów żywnościowych prepozyt kupował zboże dla zakonników, jak i - rzadziej - dla pensjonariuszy przebywa-

${ }^{111}$ Prepozyt w tej kategorii, z niewiadomych przyczyn, zawarł wydatki na księgi (100 fl.), stąd podana w źródle na k. 14r suma 4612 fl. i 18 gr. Nie uwzględnił w niej zaś inwestycji we Wroninie z 1573 r., za 70 fl., mimo że zanotował tę kwotę. 
jących $\mathrm{w}$ szpitalu ${ }^{112}$. Zaopatrywanie się na rynku w ten podstawowy produkt było sporadyczne i spowodowane przede wszystkim klęskami żywiołowymi bądź zniszczeniem majątków klasztornych. W $1582 \mathrm{r}$. nie zebrano plonów w dobrach i folwarkach klasztoru, „bo beł grad we Wroninie i pobieł"113. Nabywał prepozyt także mięso ${ }^{114}$, chleb ${ }^{115}$, tylko raz ryby ${ }^{116}$, a ponadto piwo oraz składniki do jego produkcji. Zapłacono „Jędrzejowi organiście karczmarzowi krakowskiemu za piwo które się brało a festo S. Galli usque ad diem secundam mense Augusti in Anno 1588 a to dla niedostatku zboża, który konwent popadł przez żołnierza folwarków spustoszeni, popalenie i wniwecz obrocenie"117. Zakupy produktów żywnościowych niezbyt częste i niezbyt obfite świadcza o tym, że klasztor czerpał dochody w naturaliach, nie tylko wymienione zboże czy mięso, ale i zapewne jaja, nabiał, warzywa, przede wszystkim z folwarków i majątków ziemskich należących do jego uposażenia. Niewykluczone, że źródłem zaopatrzenia w produkty przeznaczone do konsumpcji były też liczne darowizny bądź legaty, jak to się zdarzało $\mathrm{w}$ innych konwentach ${ }^{118}$. Zakupów dokonywali duchacy w momencie czasowego niedoboru naturaliów, co spowodowane były wydarzeniami zewnętrznymi lub klęskami żywiołowymi wpływającymi na rytm życia mieszkańców klasztoru w równym stopniu jak osób świeckich. Ciekawe jest natomiast to, że zapisywano w rachunkach klasztoru wydatki na żywność przeznaczoną nie tylko dla duchaków, ale i podopiecznych szpitala, zarządzanego przez świeckich prowizorów, których zdaniem miała być m.in. troska o zapewnienie żywności jego mieszkańcom ${ }^{119}$.

Klasztor nabywał też od czasu do czasu, gdy była taka potrzeba, zwierzęta żywe - konie, do celów transportowych ${ }^{120}$. Jednego kupiono na potrzeby samego prepozyta Macieja, o czym świadczy wpis: „kupie-

112 BJ 6387 Rachunki, k. 5v, 6v, 7v (do konwentu i szpitala), 8r, 10r.

113 Tamże, k. 5v.

${ }_{114}$ Tamże, k. 5v, 6v, 7v, 8r, 8v, 9r, 9v.

115 Tamże, k. 5v (piekarzowi), 7v, 8r (za mąkę pożyczoną na upieczenia chleba dla konwentu i szpitala), $9 \mathrm{v}$ (piekarzowi).

${ }_{116}$ Tamże, k. $6 \mathrm{r}-3$ fl.

117 Tamże, k. 6r, 7v, 8r, 8v, 9 r.

${ }^{118}$ M. Maciszewska, Klasztory bernardyńskie $w$ miastach Królestwa Polskiego $i$ Wielkiego Księstwa Litewskiego w latach 1453-1514. procesy fundacyjne i lokalizacja, w: Klasztor $w$ mieście..., s. 567-583; taż, Klasztor bernardyński w społeczeństwie polskim 1453-1530, Warszawa 2001; Z. Zyglewski, Średniowieczne donacje mieszczan na rzecz klasztorów kujawskich, w: Klasztor w mieście..., s. 103-110; O.M. Przybyłowicz, Rachunki klasztorne jako źródto..., s. 203, 219.

${ }^{119}$ BJ 6387 Rachunki, k. 6v, 8r, 9r.; M. Słoń, Ludzie z rachunków..., s. 447, 448.

${ }^{120}$ BJ 6387 Rachunki, k. 5r, 6v, 7r, 11r. 
łech u pana Mykolaja Habrka muzyka króla IE Moscy pare koni woźniczków i skoczem na trybunał"121. Natomiast sprawy sądowe, m.in. te toczace się przed trybunałem koronnym w Lublinie, sprawy o granice dóbr duchaków majętności i stanowiących uposażenie szpitala, pochłaniały systematycznie niemałe kwoty z budżetu zakonnego. Niejednokrotnie pożyczane były przez Regiomontanusa od osób prywatnych, jak np. w 1591 r. „Panu Mychalowskiemu pisarzowi oświęcimskiemu co mi beł pożyczeł na acta z Panem Cracowskim w Lublinie 50 fl." ${ }^{22}$ Zapożyczył się także prepozyt na $30 \mathrm{fl}$. u Stanisława Swarzychowskiego, kiedy jechał na synod do Iłży w 1583 r. ${ }^{123}$

Kilkanaście razy zapisał prepozyt Maciej jedynie imię i nazwisko osoby, której klasztor zapłacił, bez wyszczególnienia, za jakie usługi i produkty są to należności ${ }^{124}$. Pewne sumy dawano również poddanym klasztoru wymienianym najczęściej z imienia i nazwiska, jak np. Zofii Blaskowej z ul. Jaworzańskiej za służbę w folwarku $20 \mathrm{fl} .{ }^{125}$

Kilka razy na kartach pojawiła się pozycja zakup sukna bez określenia, dla kogo była materia przeznaczona lub też odwrotnie, z dokładnym wymienieniem osób, dla których dokonano wydatku: dla probantów i czeladzi. Płacono także krawcowi za wykonanie pewnych usług. Ponieważ są to kwoty niemałe - od 3 do 75 fl. i 16 gr $^{126}$ - chodzi w większości przypadków o uregulowanie należności za ten towar w dłuższym okresie, nie zaś o odnotowanie pojedynczych wypłat za konkretne zamówienia.

Największy ładunek informacji o realiach życia codziennego przynoszą wpisy na wydatki jednorazowe. I tak w 1578 r. przeorowi premonstratensów w Hebdowie przekazano 5 fl. ${ }^{127}$, a Jakubowi Czijeskiemu od roboty butów dla czeladzi oraz za sieci „alias wloki do stawów dla łowienia ryb" zapłacono za lata $1573-1575$ aż $80 \mathrm{fl} .{ }^{128} \mathrm{~W} 1581 \mathrm{r}$. Regiomontanus wykupił od pani Adamowej pewien klejnot wartości 200 fl. i kazał wykonać złotnikowi Folthinowi „sigilla conwenckie kapitulne i moje dwie srebra we dwu wielkich za siedm florenów a od roboty 20 talerów”"129. W tymże roku zginął w niewyjaśnionych okolicznościach cenny

\footnotetext{
${ }_{121}$ Tamże, k. 11r, wpis z $1591 \mathrm{r}$.

${ }_{122}$ Tamże, k. 6r, a ponadto 6v, 7v (na proces z rajcami Kalisza), 9r, 9v, 10r, 10v, 11r.

${ }^{123}$ Tamże, k. 5v.

${ }_{124}$ Tamże, k. 5r-11r.

${ }^{125}$ Tamże, k. 9v, inne zaś sługi: 6v, 8r, 9r, 10r.

${ }^{126}$ Tamże, k. 5v, 6v, 8v, 9v, 10r.

${ }_{127}$ Tamże, k. 7r (bez informacji, za co).

128 Tamże, k. 8r.

129 Tamże, k. 9r.
} 
kielich duchaków „przez księdza Jakuba Twardego u stolarza Bartosza, który stał za 60 fl., na którego miejsce kupiłem kapę złotogłową na aksamicie za fl. 40, a druga biała altembaszowa za fl. 40, ornat aksamitny czerwony na złotym dnie za z fl. 30 "130. Ponadto prepozyt zakupił kielich srebrny, stary, „pozłocisty”, i oddał go do renowacji, za co zapłacił 50 fl. ${ }^{131} \mathrm{~W} 1590$ r. zwracał księdzu Marcinowi prowincjałowi z Częstochowy „według quittu jego” wystawionego w tymże mieście 1 maja tegoż roku 10 fl. ${ }^{132}$

Maciej pomylił się dwukrotnie w podsumowaniu wydatków, którego dokonywał na dole każdej strony ${ }^{133}$. Suma wszystkich należności za lata 1571-1591 jest również inna niż wynikałoby to z podliczenia kwot z wszystkich kart - $4007 \mathrm{fl}$. i $12 \mathrm{gr}$, podczas gdy duchak zapisał 4587 fl. i $14 \mathrm{gr}^{134}$. Rękopis w tej części jest kompletny, a zapisy prowadzone były chronologicznie, trudno więc określić, czym należy tłumaczyć tę różnicę. Przypuszczam, że oprócz zapisanej sumy włączył jeszcze Maciej inne kwoty do ogólnej sumy debitorum ${ }^{135}$. Być może dodał do wydatków cyrografy, których dwa rejestry, w tym jeden częściowy, wspominany wcześniej, rozpoczynający się liczbą porządkową dziewięć, znajdują się w źródle w dwóch miejscach.

$\mathrm{Na}$ kolejnych 18 kartach odnotowywał Regiomontanus grupy wydatków stałych: Merces familiae deservia annuatim soluta (k. 16-34). Członkami familii klasztornej byli: piekarz, piwowar, słodownicy, kantor, organista, kalkant, dzwonnik, kucharz, kowal i sługi. Wydatki zapisywano rocznie dla poszczególnych osób i wykonywane przez nich prace oraz usługi.

Na pieczywo i za pracę piekarza w latach 1570-1587 wydali duchacy 703 fl. i 24 gr. W podsumowaniu wydatków na ten cel widnieje kwota 713 fl. i 14 gr, która wynika z pomyłki o 10 fl., uczynionej na jednej z kart ${ }^{136}$. W pierwszych dwóch latach płacono rocznie $32 \mathrm{fl}$. i 8 gr, w kolejnych sześciu $41 \mathrm{fl}$. i 10 gr, a w następnych 42 fl. i 14 gr, bo „ubogich beło przybyło do szpitala”. Ta uwaga wskazuje więc na troskę

${ }^{130}$ Tamże, 9v.

${ }^{131}$ Tamże.

132 Tamże, k. 10v.

${ }^{133}$ Tamże, k. 9r - 468 fl. i 20 gr, a wychodzi 468 i 40 gr, czyli 469 fl. i 10 gr; k. 10r - 387 i 17 gr, a wychodzi 378 i 37 gr, czyli 388 fl. i 7 gr.

${ }^{134}$ Tamże, k. 12r.

${ }^{135} \mathrm{O}$ umiejętności liczenia wśród członków elity społecznej zob. A. Wyczański, Próba oceny umiejętności liczenia małopolskiej komisji lustracyjnej (1564-1565), „Odrodzenie i Reformacja w Polsce” 50, 2006, s. 61-73.

${ }^{136}$ BJ 6387 Rachunki, k. 18r. Błąd na k. 17v, zamiast 254 fl. i 14 gr wpisano $264 \mathrm{fl}$. i $14 \mathrm{gr}$. 
prepozyta nie tylko o braci, ale także o ubogich, choć dbać o nich mieli w pierwszym rzędzie prowizorzy świeccy.

Ciekawą informację zapisał Regiomontanus pod rokiem 1587: „beło interregnum skąd żołnierze chowano, którzy mij folwarki pustoszeli, splondrowali i popaleli, gdziem musiał kupować zboże, którem płacieł ćwiertnię po kopie i od tegom czasu już począł dawać przez xiędza Stanisława z Wronina safarza naszego pieniędzmi co się pokaże z regestru jego"137. Piwowar i słodownicy otrzymali w latach 1570-1587 aż $1795 \mathrm{fl}$. i $4 \mathrm{gr}^{138}$. Rocznie wydatkowano na ten cel - za wyjątkiem 1587 r. 102 fl. i 18 gr. Prepozyt dokładnie zapisał, co składało się na tę kwotę. Pozwala to na poznanie procesu produkcji piwa w konwencie duchaków i jej wielkości: 18 warów piwa - „na każde trzy niedziele jeden war”, czyli ok. 4875 litrów (przyjmując achtel za 195 l) ${ }^{139}$. Dziennie spożytkowano zatem w klasztorze ponad 232 litry piwa. Najprawdopodobniej część z tego przekazywano do szpitala, jak i również członkom familii klasztornej. Nie znamy wielkości zgromadzenia duchaków w tym czasie i nie dysponujemy informacjami o dziennych racjach piwa. Jeśli przyjmiemy jednak minimalne spożycie piwa na poziomie 2 litrów dziennie na osobę (wśród pracowników folwarków wynosiło 1,2 litra, ale standard życia w klasztorze był pewnie wyższy) ${ }^{140}$ to można $\mathrm{z}$ dużą dozą prawdopodobieństwa uznać, że trunek każdego dnia spożywało ponad 100 osób (116, gdy przyjmujemy minimalne spożycie).

Za każdą warę piwowar otrzymywał 16 gr, co rocznie dawało $9 \mathrm{fl}$. i $18 \mathrm{gr}$, a ponadto dostawał wyżywienie z konwentu oraz flaszkę piwa ${ }^{141}$. Dwaj słodownicy od każdej sztuki słodu płacone mieli 8 gr., „a sztuk do roku słodu $10 \mathrm{w}$ każdej sztuce po 7 ćwiercień”. Corocznie oznaczało to wydatek $5 \mathrm{fl}$. i $10 \mathrm{gr}^{142}$. Słodownicy także byli na wikcie klasztornym. Prepozyt zapisał bowiem skrupulatnie czas potrzebny do przygotowania słodu: „kiedy robia, gdyż musi moknać pszenica w korycie dni 4. Piątego dnia wyrzucić, 4 dni na gumnie, 4 dni suszyć to uczyni 13 dni" ${ }^{143}$, co łącznie kosztowało klasztor 30 fl. i 28 gr. Do produkcji

${ }_{137}^{13}$ Tamże, k. 17v, 18r.

138 Tamże, k. 18v-21v.

${ }^{139}$ Według S. Dryi, Krakowskie miary piwowarskie w XVI wieku, „Kwartalnik Historii Kultury Materialnej” 59, 2011, s. 12, 1 wara dawała 25 achteli lub beczek, z kolei 1 achtel liczył 72 garnce, czyli 194,39-197,87 litra.

${ }^{140}$ A. Wyczański, Studia nad konsumpcja żywności w Polsce $w$ XVI i pierwszej połowie XVII w., Warszawa 1969, s. 112.

${ }^{141}$ BJ 6387 Rachunki, k. 18v.

142 Tamże.

${ }^{143}$ Tamże, k. 18v i $19 r$. 
potrzebne było też drewno, do każdego słodu wydatkowano na to grzywnę lub nawet więcej, co oznaczało kwotę roczna 16 fl., do każdego zaś waru piwa przeznaczano po cztery drwa - każde za 15 gr, „czasem i więcej”, co daje 36 fl. Ponadto do każdego waru dwie ćwiertnie chmielu, co kosztowało $36 \mathrm{fl}$.

W 1587 r. zrobiono tylko pięć warów, z których dwa się „popsowały”. Potem z powodu interregnum i zniszczenia folwarków przez żołnierzy nie można było przygotowywać napoju ze zboża własnego, tj. upraw z dóbr szpitalnych i zakonnych w klasztornym browarze. Piwowarowi i słodownikom zapłacił więc Maciej jedynie za pół roku pracy, co z wydatkami na drewno dało kwotę 45 fl. i 8 gr. Regiomontanus zaś musiał zakupić piwo od jednego z mieszczan krakowskich, który to wydatek został zapisany w innych księgach: „a festo S. Galli Annum hoc 1587 usque ad primam mensis Decembris przez księdza Stanisława z Wronina szaffarza naszego brało się piwo achtelmy od Jędrzeja organisty kaczmarza mieszczanina krakowskiego co się pokaże według regestru jego wiele się zapłaciło"144.

Kantor i organista corocznie otrzymywali po $4 \mathrm{fl}$. i $20 \mathrm{gr}$, na co składało się wyżywienie i zapłata (,na każde suche dni po talieru staremu”), w latach 1570-1590 dało to kwotę 196 fl. ${ }^{145}$ Kalkant poruszajacy miechami organów dostawał „na każde suche dni po 6 groszy strawa”, co rocznie wyniosło $24 \mathrm{gr}$, a w latach 1570-1590 - 16 fl. i $24 \mathrm{gr}^{146}$. Dzwonnikom na suche dni wydawano po $12 \mathrm{gr}$, co wraz ze strawą otrzymywana z konwentu dawało corocznie $1 \mathrm{fl}$. i 18 gr, a przez 20 lat kwotę 33 fl. i $18 \mathrm{gr}^{147}$.

Na utrzymaniu zakonników był też klasztorny kucharz bądź kucharka, która to osoba za przygotowywanie jadła otrzymywała rocznie $4 \mathrm{fl}$. i $24 \mathrm{gr}$, co przez 20 lat dało kwotę $91 \mathrm{fl}$. i $6 \mathrm{gr}^{148}$. Sługa o imieniu Uschnacht, który „w piecach pala, podworze umiata, drwa rąbie tak do kuchnie jako i do pieców albo co potrzeba czyni”, rocznie otrzymywał $2 \mathrm{fl}$., a ponadto klasztor kupował mu ubranie: „suknie za kope i groszy 12, kożuch za grzywnę, buty 24 gr, podszycia dwoje po 8 gr"149. W sumie jego utrzymanie zamykało się rocznie w kwocie 5 fl. i 26 gr, przez 20 lat dało zaś sumę $123 \mathrm{fl}$. i $6 \mathrm{gr}^{150}$. Nie było to wynagrodzenie

\footnotetext{
${ }^{144}$ Tamże, k. 21v.

145 Tamże, k. 22r-23v.

146 Tamże, k. 24r-24v.

147 Tamże, k. 25r-25v

148 Tamże, k. 26r-26v.

149 Tamże, k. 27r-27v.

150 Tamże.
} 


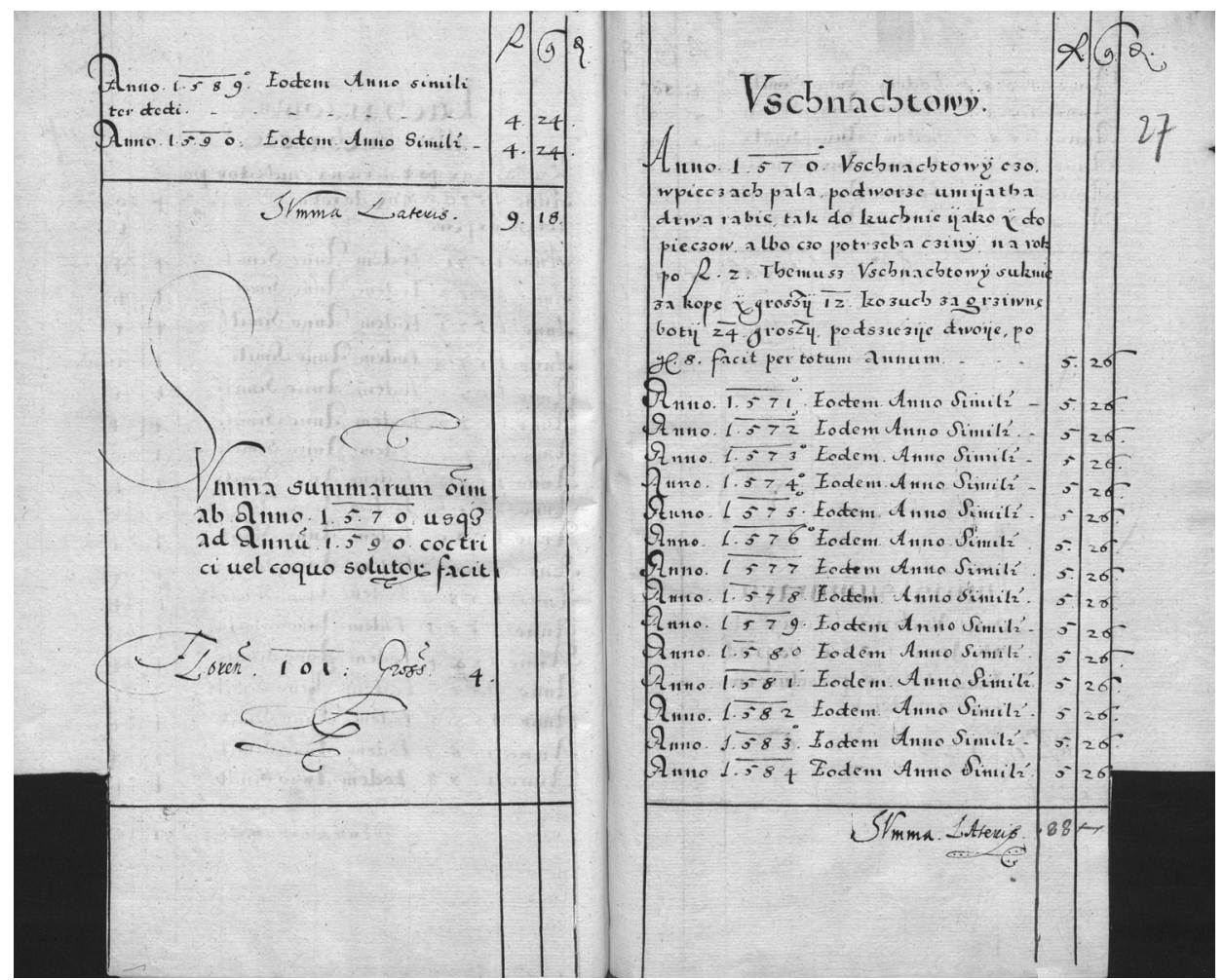

BJ 6387 Rachunki, III, k. 26v-27r.

wygórowane, odpowiadało stawkom rynkowym robotników miejskich i parobków wiejskich ${ }^{151}$. Jan Rybka, stary sługa, który m.in. nosił chleb do szpitala oraz wykonywał ,insze domowe potrzeby”, rocznie dostawał 1 fl. i 18 gr, co po dodaniu wydatków na jego ubiór: suknie, kożuch, buty, podszycie sumowało się przez dwanaście miesięcy do kwoty $5 \mathrm{fl}$. i 10 gr $^{152}$. Jan zmarł w 1585 r., a jego utrzymanie kosztowało konwent krakowski 80 fl. przez 15 lat $^{153}$.

Kapłani określeni mianem sacerdotes sapientiae otrzymywali rocznie iuxta consuetudinem antiquam po 2 fl. do 1586 r., a w kryzysowym 1587 i kolejnych trzech latach po $1 \mathrm{fl}$. i 5 gr, co dało łącznie przez 20 lat kwotę 38 fl. i 20 gr $^{154}$. Na karcie 30 Regiomontanus wymienił osoby,

${ }^{151}$ J. Pelc, Ceny w Krakowie w latach 1369-1600, Lwów 1935, s. 93; A. Kamler, Chtopi jako pracownicy najemni na wsi małopolskiej $w$ XVI i pierwszej połowie XVII wieku, Warszawa 2005, s. 146.

${ }^{152}$ BJ 6387 Rachunki, k. 28r.

${ }_{153}$ Tamże, k. 28v.

${ }^{154}$ Tamże, k. 29r-29v. 
które dostały w 1570 r. kolędę. Byli to: kapłani - każdy z sześciu otrzymał po $1 \mathrm{fl}$., senior szkoły - $1 \mathrm{fl}$. i $5 \mathrm{gr}$, organista, kantor, młodzieńcy - po 1 fl., pewien Lokat - 15 gr, kucharka i ceklarze (stróże porządku) - po 8 gr, kalkant - 4 gr, dzwonnicy i piwowar - po 12 gr, słodownicy, łaziebnicy i piekarz - po 10 gr, trębacze - 20 gr, bronni i trzej nauczyciele z kolegium - po 24 gr, sługa Rybka - 6 gr, do bursy pauperum dano 15 gr, czeladzi w folwarkach we Wroninie i Krowodrzy $1 \mathrm{fl}$. i 18 gr, mamkom w szpitalu opiekującym się dziećmi - $1 \mathrm{fl}$. i 5 gr, a ponadto za 12 gr pieczenie i warzywa, sługom domowym Macieja $1 \mathrm{fl}$. oraz kolędy in publicum za $3 \mathrm{fl} .{ }^{155} \mathrm{~W}$ sumie jałmużny rozdał prepozyt 25 fl. i 22 gr, której to kwoty nie da się jednak odczytać z podsumowania ze względu na defekt rękopisu ${ }^{156}$. Poniżej poinformował jednak, że w kolejnych latach, do 1586 r., similiter przeznaczył Regiomontanus na ten cel $36 \mathrm{fl}$. i $28 \mathrm{gr}^{157}$. W $1587 \mathrm{r}$. kolędy rozdał jedynie 10 fl. i 26 gr, w 1588 r. tylko 8 fl., w 1589 zaś 9 fl. i 20 gr, a w 1590 - 7 fl. Zmniejszajace się kwoty świadczą najprawdopodobniej o pogarszającej się sytuacji finansowej wspólnoty, co spowodowane być mogło spustoszeniami majątków i folwarków w czasie interregnum, o których Maciej wspominał kilka razy na kartach księgi rachunkowej. W sumie w latach 1570-1590 wydatkował na cele charytatywne $612 \mathrm{fl}$. i $8 \mathrm{gr}^{158}$.

Kolejna pozycje w rachunkach stanowiły wypłaty pro ratione balnei dla kapłanów i członków familii klasztornej. Kapłani - w 1570 r. było ich sześciu - otrzymali po 12 gr, a kantor i wicekantor oraz senior, organista i kucharz po groszu, pozostali zaś, wraz z exterioribusi pueris, 8 gr. Rocznie przeznaczył na ten cel prepozyt 3 fl. i 10 gr. Przekazywał pieniądze zawsze na Wielkanoc. Przez 20 lat uczyniło to wydatek rzędu 40 fl. ${ }^{159} \mathrm{~W} 1587 \mathrm{r}$. łaźnia klasztorna, znajdująca się tak jak cały kompleks budynków duchaków tuż przy murach miejskich, uległa zniszczeniu z powodu walk i oblężenia Krakowa w czasie interregnum: „destructum est per subdites, qui tempore obsidionis et conflagrationis se se ad conventum cum pecoribus et rebus domesticis conversi sunt quo quidem balneum ob defectu conventus quo per milites passus est iam restaurare non potui" ${ }^{160}$.

\footnotetext{
155 Tamże, k. 30r-30v.

${ }^{156}$ Tamże, k. 31v (widać tylko 28 gr).

157 Tamże.

${ }_{158}$ Tamże, k. 31r (w rękopisie pozostawiono pod rachunkiem puste miejsce, brak wpisu Regiomontanusa).

159 Tamże, k. 31v-32r.

160 Tamże, k. 32r.
} 
Na następnej karcie znalazły się wydatki dla kowala Piotra uczynione w latach 1574-1576 za różne wykonane przez niego prace i usługi oraz za dostarczone do klasztoru rzeczy, m.in. „,naprzód od podków wedlug regestru i karbu kop 2 i 18 po pułtoru groszu facit 6 fl. i 27 gr", ponadto od naprawy koryta, wozu, od ostrzenia żelaz, od nakładania lemiesza, od nakładania radlice, za dwie „blasze do rynny sadzawczanej”, łańcuchy, wagi, zawias do komory, czoprzinkę i osiem czopów, koła, stusze i stusziny ${ }^{161}$. Za wyżej wymienione towary i usługi otrzymywał od 5 gr do ponad $15 \mathrm{fl}$. W sumie zapłacił Regiomontanus kowalowi w 1574 r. 33 fl. i 9 gr $^{162}$, w 1575 - 33 fl. i 24 gr, w 1576 - 23 fl. i $15 \mathrm{gr}^{163}$. Pod rokiem 1577 zapisał natomiast: „Ab anno 1577 incipiendo usque ad annum 1579 porachowałem się $\mathrm{z}$ nim i zostałech mu za robotę których mu zapłacieł według mego cyrograffu jemu na się danego i z wytrąceniem dziesięciny 70 fl." ${ }^{164}$ Nie wymienił więc poszczególnych robót i usług kowala, podobnie jak w następnej dekadzie: „Ab anno 1579 usque ad annum 1589 brała się robota u Pa" - na tym zapis się urywa ${ }^{165}$. Kolejne karty, znacznie zniszczone (urwana część w jednej trzeciej rękopisu) obejmuja Contributiones tam pro synodo quam etiam pro Tribunali Lublinensi ${ }^{166}$. Z zachowanych zapisów wiadomo, że w 1577 r. na synod przekazał 35 fl. i 10 gr, ad nuntium Romanum 2 fl. i 28 gr, a na trybunał wydatkował 5 fl.: „na który na każdy rok ustawiono, aby po 5 fl. pro iudicibus spiritualibus płacono, począłem tedy płacić..."167. Kwota przeznaczona na sędziów w trybunale była płacona do 1592 r. ${ }^{168}$

Ostatnie karty (k. 37-41) to informacje o kontrybucjach dawanych z podkrakowskich wsi klasztornych oraz kościołów tamże, jeśli prebenda należała do zgromadzenia de Saxia. Wymieniono: Kurdwanów, Wronin, Wieliczkę, Zabłoczę, Zborów, Szczegłów, Szurowsky ${ }^{169}$. Do Woli i Rząki nie przekazywał Maciej żadnych pieniędzy, przy tej ostatniej miejscowości zapisał zaś: „nie daję bo decima datur plebano

${ }^{161}$ Tamże, k. 32v, 33r, 33v.

162 Tamże, na k. 32v nie ma kwoty przy summa latus, a wynosi ona $14 \mathrm{fl}$. i $10 \mathrm{gr}$, na k. 33 summa latus zapisana jako 16 fl. i 14 gr, a po zliczeniu wynosi 16 fl. i 24 gr; na k. 33v podsumowano wydatki na karcie, włączając do 1575 r. zapisy wydatkowanych kwot za 1574 r., tj. 65 gr.

${ }_{163}$ Tamże, k. 35r (brak summa latus, a wynosi ona 8 fl. i 26 gr).

${ }^{164}$ Tamże, k. 35r.

${ }_{165}$ Tamże, k. 35v.

166 Tamże, k. 36r-36v.

167 Tamże.

168 Tamże, k. 36r.

${ }^{169}$ Tamże, k. 37r, 37v, 38r. 
Biezanoviensi" ${ }^{170}$. Informacje dotyczą lat $1573,1576,1577$. Przeznaczył na ten cel 24 fl., w 1578 r. - 26 fl. ${ }^{171}$, a w 1579 - 35 fl. i 15 gr $^{172}$, gdyż wzrosły kwoty należności, najwięcej, bo o $15 \%$ - w porównaniu z pierwszymi latami - do Krowodrzy: z 10 fl. do 15 fl. iuxta constitutionem generalem $^{173}$. W latach 1580-1582 przekazywał prepozyt duchaków 33 fl. i 25 gr $^{174}$. Rękopis kończy się zapiskami dotyczącymi kolejnego roku. Wiadomo, że nie dał wówczas żadnych pieniędzy do Krowodrzy, gdyż „Pan Szaszin dawał, któremu ja arendował, iż chłopy poczęły rebelisować i nie chceli robić iuxta quietacionem illius" ${ }^{175}$. Można przypuszczać, że kontrybucje z tychże dóbr ziemskich płacone były do końca rzadów Regiomontanusa, a informacje o nich znalazły się na następnych, niezachowanych kartach.

Tabela 4. Stałe wydatki duchaków w latach 1571-1591

\begin{tabular}{l|c|c}
\hline Wyszczególnienie & Suma w groszach & Odsetek \\
\hline Piekarz & 22412 & 17,2 \\
\hline Piwowar & 53854 & 41,4 \\
\hline Kantor & 2940 & 2,3 \\
\hline Organista & 2940 & 2,3 \\
\hline Kalkant & 504 & 0,4 \\
\hline Dzwonnik & 1008 & 0,8 \\
\hline Kucharz & 3024 & 2,3 \\
\hline Usznat & 3696 & 2,8 \\
\hline Rybka & 2400 & 1,8 \\
\hline Kapłani & 1125 & 0,9 \\
\hline Kolęda & 19476 & 15,0 \\
\hline Łaźnia & 2100 & 1,6 \\
\hline Kowal & 5000 & 3,8 \\
\hline Trybunał & 1800 & 1,4 \\
\hline Contributio & 7881 & 6,1 \\
\hline Razem & 130160 & 100 \\
\hline
\end{tabular}

Źródło: BJ 6387 Rachunki, k. 14r-34r.

\footnotetext{
170 Tamże, k. 37r.

${ }_{171}$ Tamże, k. 38r, 38v.

172 Tamże, k. 38v.

173 Tamże.

174 Tamże, k. 39r, 39v, 40r.

175 Tamże, k. 40r.
} 
Różnorodne należności wobec osób prywatnych wpisane zbiorczo za lata 1571-1591 oraz długi przejęte przez Macieja po poprzednikach, których spłatę odnotował prepozyt ponownie zbiorczo w latach 1570-1579 (nie zaś po każdym rokiem), uniemożliwiaja przedstawienie wszystkich wydatków zapisanych w rękopisie w skali rocznej.

W tabeli zestawiłam natomiast stałe pozycje wydatków Regiomontanusa, głównie należności dla familii klasztornej, ale nie tylko.

Niezależnie od zastrzeżeń czynionych powyżej co do sposobu zapisywania informacji (nie zawsze z podaniem roku) oraz niekompletności rękopisu rachunki Regiomontanusa są niezwykle cennym źródłem. Pozwalają na wejrzenie przede wszystkim w realia krakowskiej wspólnoty zakonnej de Saxia oraz w niewielkim stopniu szpitala prowadzonego przez duchaków na początku epoki nowożytnej. Nie daja pełnego obrazu, lecz prezentuja wycinek świata rzeczy i ludzi, ukazują pewna symbiozę współistnienia (współfinansowania) klasztoru i placówki opiekuńczej.

Ich bezsprzeczna wartość wynika z obiektywnego i wymiernego opisu danych rachunkowych (w przeciwieństwie np. do subiektywnych źródeł narracyjnych) i całkiem imponującego ładunku informacji. Zgromadzone dane dotycza nie tylko spraw finansowo-gospodarczych i ekonomii klasztoru, ale też sposobu funkcjonowania konwentu duchaków i placówki dobroczynności publicznej prowadzonej przez zakonników w Krakowie, inwestycji budowlanych podejmowanych przez klasztor na miejscu oraz w folwarkach i wsiach konwenckich, sposobu zarządzania własnościa ziemska. Pozwalaja na wejrzenie w mikroświat więzi społecznych tak wspólnoty - familii klasztornej, jak i kontaktów z przedstawicielami świata zewnętrznego - osobami świeckimi, głównie mieszczanami położonego w pobliżu klasztoru Kleparza oraz duchownymi, przede wszystkim krakowskimi, choć nie tylko. Informacje o familii klasztornej zwracają uwagę na niewielką liczbę stałych sług związanych z działalnością wspólnoty tworzonej przez kilkudziesięciu (?) biorac pod uwage ilość warzonego bądź kupowanego w latach klęsk piwa - zakonników. Wskazuja też na korzystanie z usług miejscowych - głównie kleparskich i kazimierskich - rzemieślników oraz kontakty z mieszczanami trudniących się handlem. Przynoszą wreszcie konkretne informacje o kształtowaniu się cen i wynagrodzeń w końcu XVI w. oraz pozwalaja uzupełnić zestawy danych przygotowanych przed 80 laty przez Juliusza Pelca. 


\section{Bibliografia}

Przybyłowicz O.M., „Dla prędszego wydawania obiadu...”. Rozporzadzenia wizytatorów dotyczace stołu i positków w klasztorach żeńskich diecezji krakowskiej z końca XVI- połowy XVII wieku, w: Rzeczy i ludzie. Kultura materialna $w$ późnym średniowieczu $i$ w okresie nowożytnym. Studia dedykowane Marii Dabrowskiej, red. M. Bis, W. Bis, Warszawa 2014, s. 241-266.

Przybyłowicz O.M., Jak panny zakonne rozliczały się? Księi rachunkowe jako źródto do badań nad polskimi klasztorami żeńskimi $w$ XVI-XVIII $w$., w: Klasztor $w$ gospodarce średniowiecznej $i$ nowożytnej, red. M. Derwich, Wrocław 2013, s. 101-114.

Przybyłowicz O.M., „Pamięć obłóczyn kożdy probantki”. Ceremonia obłóczyn $w$ świetle rękopisu Modus suscipiendi novitias ad habitum S. Clarae z 1600 r. z klasztoru klarysek gnieźnieńskich, „Hereditas Monasteriorum” 2, 2013, s. 179-194.

Przybyłowicz O.M., Pobożność przedstawicielek rodów panujacych Europy Środkowej (XIII-pocz. XIV w.). Fenomen popularności franciszkanizmu: inspiracje - modele, w: Per mulierem... Kobieta $w$ dawnej Polsce - $w$ średniowieczu $i$ w dobie staropolskiej, red. K. Justyniarska-Chojak, S. Konarska-Zimnicka, Warszawa 2012.

Przybyłowicz O.M., Rachunki klasztorne jako źródto do poznania realiów życia klasztornego. Najstarsza zachowana ksiega rachunkowa klarysek ze Starego Sacza, w: Realia życia codziennego w Europie Środkowej ze szczególnym uwzględnieniem Ślaska, red. A. Barciak, Katowice 2011 (Kultura Europy Środkowej, 14), s. 197-220.

Przybyłowicz O.M., Spory klarysek starosadeckich o cło z Bardiowem w epoce średniowiecza, „Rocznik Sądecki” 39, 2011, s. 53-72.

Przybyłowicz O.M, Pobóg-Lenartowicz A., Refleksje nad badaniami na temat kobiet $w$ średniowiecznej Polsce, w: Dzieje kobiet w Polsce, red. K.A. Makowski, Poznań 2014, s. 29-52.

Olga Miriam Przybyłowicz

The account book of the Prepositor of the Monastery of the Holy Spirit de Saxia, Maciej Regiomontanus, from the years 1570-1591. People and things (Summary)

The article analyses the oldest surviving account book of the Monastery of the Holy Spirit de Saxia. Dating from the latter half of the sixteenth century (1570-1591), the manuscript was written by Regiomontanus of Konigsberg. It is a valuable document, although the records it contains concern only expenditures. Not only is it more than four hundred years old but the expenditures were recorded over a very long period. Except for the Latin headings of particular 
sections of the expenditures, Regiomontanus relied on Polish for recording the data. It is an interesting detail which - especially in view of the fact that the register was kept by a clergyman - proves that in the latter half of the sixteenth century the national language began to grow in importance.

The source shows the community oriented toward offering assistance to the needy in the big city. It provides information about the money spent on the congregation as well as on the hospital and the monastery school, shedding light on the social bonds formed by the monks both within the Monastery and through their contacts with the outside world, with the inhabitants of the city, especially those who rendered services to the whole community or who supported the Order financially.

Key words: account books, monasticism, accounting 